Article

\title{
Examination of the Sustainable Rural Tourism Potential of the Brčko District of Bosnia and Herzegovina Using a Fuzzy Approach Based on Group Decision Making
}

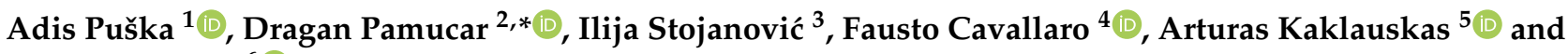 \\ Abbas Mardani ${ }^{6}$ (D) \\ 1 Institute for Scientific Research and Development, Brcko District BiH, Bulevara mira 30, \\ 76120 Brčko, Bosnia and Herzegovina; adispuska@yahoo.com \\ 2 Department of Logistics, Military Academy, University of Defence in Belgrade, Pavla Jurišića Šturma 33, \\ 11000 Belgrade, Serbia \\ 3 College of Business Studies, Al Ghurair University, Dubai P.O. Box 37374, UAE; \\ ilija.stojanovic1976@gmail.com \\ 4 Department of Economics, University of Molise, Via De Sanctis, 86100 Campobasso, Italy; cavallaro@unimol.it \\ 5 Faculty of Civil Engineering, Vilnius Gediminas Technical University, 10221 Vilnius, Lithuania; \\ arturas.kaklauskas@vgtu.lt \\ 6 Department of Marketing, Muma College of Business, University of South Florida, Tampa, FL 33813, USA; \\ mabbas3@liveutm.onmicrosoft.com \\ * Correspondence: dragan.pamucar@va.mod.gov.rs
}

Citation: Puška, A.; Pamucar, D. Stojanović, I.; Cavallaro, F.; Kaklauskas, A.; Mardani, A.

Examination of the Sustainable Rural Tourism Potential of the Brčko District of Bosnia and Herzegovina Using a Fuzzy Approach Based on Group Decision Making. Sustainability 2021, 13, 583 https://doi.org/10.3390/su13020583

Received: 17 December 2020 Accepted: 7 January 2021 Published: 9 January 2021

Publisher's Note: MDPI stays neutral with regard to jurisdictional clai$\mathrm{ms}$ in published maps and institutional affiliations.

Copyright: (C) 2021 by the authors. Licensee MDPI, Basel, Switzerland. This article is an open access article distributed under the terms and conditions of the Creative Commons Attribution (CC BY) license (https:// creativecommons.org/licenses/by/ $4.0 /)$.
Abstract: Tourism is an economic activity with great contribution for the development of many countries. To develop rural areas, tourism is especially important and need to be improved in these areas. The Government of Brčko District of Bosnia and Herzegovina has decided to have tourism improvement as one of main objectives in their development strategy focusing on better conditions for development of tourism. Investments in tourism should be applied to the entire area of the Brčko District. Since Brčko District mainly consists of rural areas, it is necessary to invest in rural tourism. The first step of this study was to determine the tourist potential of rural areas. The determination of rural tourist potential in Brčko District was carried out with the assistance of the Brčko District Government. For this purpose, the method of expert decision-making was used, and three experts were selected who evaluated six rural settlements. To obtain results based on expert evaluation, two multi-criteria methods were used: the Full Consistency Method (FUCOM) for determining the importance of criteria and the fuzzy Measurement Alternatives and Ranking according to the COmpromise Solution (MARCOS) method to rank rural settlements in terms of their tourism potential. The results showed that the settlement of Bijela has the best rural tourist potential, while the settlement of Grbavica has the least potential. The results obtained by applying this model showed how rural tourism in Brčko District can be improved. The research model for testing the tourism potential has shown good results and can be applied in other branches of tourism with some adaptation to certain branches of tourism.

Keywords: rural tourism; tourism potential; FUCOM method; MARCOS method; expert assessment

\section{Introduction}

Tourism contributes to economic growth and development of the world economy. It represents one of the largest industries in the world [1]. In certain geographical regions, tourism has the effect of increasing employment and it is a very important socio-economic driver [2]. Especially in rural areas, tourism is a tool for improving these areas because agricultural activity is unstable and unpredictable [3]. The recession in rural areas is a general global phenomenon that is the result of industrial revolution, so tourism and various other activities are becoming important for development of rural areas [4] in order 
to improve these areas. As a result, the importance of the agricultural sector in rural areas is declining and increasing attention is being paid to tourism [5].

Rural tourism activities require efforts by the local community to attract the attention of potential tourists to visit the area through event planning [6]. To attract the attention of tourists, the rural area should possess tourist potential. If the rural area has no potential, then it is difficult to develop the tourist offer. Before the tourist offer is developed, it is necessary to research the tourist potential of a certain area.

The focus of this study is tourism rural potential of Brčko District. Within the development strategy of Brčko District, it is stated that development of Brčko District should be based on tourism, agriculture, and entrepreneurship. Brčko District is an independent administrative unit of Bosnia and Herzegovina located in the northeast of the country. Brčko District has a tradition of various forms of tourism and very good opportunities for development of rural tourism. The model for determining the rural tourist potential was developed on the example of Brčko District.

Criteria for rural tourism potential can be different in natural, cultural, historical, and socioeconomic [7]. To assess rural tourism potential, it is necessary to apply the overall approach of evaluating the criteria of tourism potential. Due to the existence of multiple criteria, this decision problem is performed using the method of multi-criteria analysis (MCDA). MCDA is used when it is necessary to compare alternatives using certain criteria [8]. The assessment of rural tourism potential in Brčko District was performed using a decision-making model based on the application of fuzzy logic. Fuzzy logic is applied to complex problems that cannot be easily described by traditional mathematical models. It provides a broader framework compared to classical logic and enables development of models that reflect human thinking in real problems.

To assess the rural tourism potential, it was necessary to develop a model that allows experts to assess individual alternatives based on the set criteria. Based on these assessments, the experts assessed the rural tourism potential, looked at their pros and cons and provided guidelines for improvements to the rural potential in Brčko District. The significance of this study is that an innovative research model has been created that was used to examine the rural tourism potential. In previous studies, different approaches were used to measure tourism potential, a mathematical model for evaluating criterion weights [7], an assessment of demand for attractiveness of tourism potential [8], estimates of tourism potential and estimates of discrimination parameters [9], identifying key success factors, risks and tourism potential in rural and mountainous regions [5], tourist sites for Geocaching [10], the potential of coastal rural tourism [2], examining the potential for tourism development in a focused economy [11]. It can be concluded that examining rural tourism potential through a decision-making model represents a new approach in solving this problem.

The contribution of this study can be found in a new way of evaluating tourism potential using expert assessments and using fuzzy logic. The model was used to evaluate rural tourism potential and to determine the strengths and weaknesses of individual rural tourist settlements. The application of a new approach based on the principles of sustainability will enable the improvement of rural tourism, while respecting the responsible use of natural resources and the preservation and nurturing of culture and tradition in the observed areas. All this aims to strengthen rural areas through tourism development. In addition, the guidelines were provided for improving rural tourism potential in Brčko District. The obtained research results interpret the current state of rural tourism potential in Brčko District and provide the necessary information to improve the tourist offer. This research will serve the rural settlements in Brčko District to look at the current tourism offer and to improve the tourist offer by implementing the guidelines obtained in this research. The research will also support managers of certain tourism capacities to improve their business. With development of the tourism offer, it will influence the development of the entire local community.

The aims of this study are focused on: 
(1) Create a model for measuring rural tourism potential

(2) Examine the current situation regarding the tourist offer

(3) Rank rural tourism potentials in Brčko District

(4) Provide guidelines for improving the tourist offer in Brčko District.

In addition to the Introduction, this paper consists of five sections. The second section provides a theoretical framework for examining tourism potential, presents the rural tourist potential of the Brčko District, and reviews the previous work in determining the tourist potential and attractiveness of certain locations. The third section of the paper explains the research methodology, the research model, the fuzzy methods used and the way the data were collected for the purposes of this study. In the fourth section, the results of examination of rural tourism potential are presented using a model and fuzzy approach. In the fifth section of the paper, the research results are examined, and the obtained results are discussed. In addition, this section provides guidelines for improving rural tourism potential in Brčko District. In conclusion, the most important results, shortcomings of this study and guidelines for future research are given.

\section{Literature Review}

\subsection{Rural Tourism}

Rural tourism is a form of tourism in rural areas within the natural environment where tourists are offered certain services and activities [12], in order to develop rural settlements and improve the living standard of the population in these settlements. Two characteristics of rural tourism are: it employs the population of rural areas and uses the existing rural infrastructure and resources as a tourist offer [13]. Tourism is a driver of rural development. Tourism in rural settlements provides certain benefits for the local economy, namely employment opportunities in the tourism and traditional sector, opportunities for income growth, creating a new market for local products, reviving local culture and strengthening local pride [14]. Rural tourism supports the preservation of local identity, tradition, and customs [15]. The development of tourism in rural settlements also affects other sectors such as agriculture, food production, local products in the form of handicrafts which can contribute to the well-being of the entire local community [16].

However, rural tourism is sometimes not the best solution for development of these areas. The application of rural tourism can affect the reduction of income, instability in business, the realization of low incomes, etc. [5]. Therefore, it is necessary to work on the promotion of all activities in rural areas, where tourism is an addition to existing activities in rural areas. In development of rural tourism, it is necessary to approach in a systematic way and conduct a common policy of development of rural settlements through tourism [13]. By applying this approach, rural tourism can contribute to the development of local areas. It should be noted that rural tourism is not a substitute for agriculture, but an upgrade of the existing business among rural residents [15].

Rural tourism encompasses holistic rural activities such as: agricultural production, promotion of rural lifestyle and rural facilities to attract people from urban and rural areas [17]. Therefore, rural tourism is becoming increasingly popular with the urban population and it is becoming an alternative to mass tourism [18]. What sets rural tourism apart from other forms of tourism is that it attracts tourists by offering a peaceful environment and nostalgia for old ways of life [19]. Rural tourism attracts those tourists who are looking for emotional experiences. In rural tourism, the starting point should be intercultural interaction and a way to bring the rural way of life closer to tourists. Tourists will thus not only be passive consumers and thus social capital in tourism will be developed [20].

Sometimes rural tourism is equated with farm tourism, but rural tourism is not just farm accommodation [21]. When conducting rural tourism, tourists will get acquainted with the rural way of life [22], but they will also get acquainted with other tourist products available to the rural community. Increasing attention in rural tourism is paid to historic buildings, traditional rural folklore, nature, and landscape [23]. Therefore, rural tourism is a broader term than farm tourism and includes other tourism products offered in rural 
areas. Farm tourism should be an integral part of the rural tourism offer, but this form of tourism is not the only form of tourism. In rural areas, there are other forms of tourism such as: green tourism, mountain tourism, gastronomic tourism, equestrian tourism, hunting tourism and other forms of tourism [24]. Therefore, when evaluating rural tourism, it is necessary to apply a holistic approach and include all the factors that are key to the success of this type of tourism.

\subsection{Tourism Potential}

Assessing the tourism potential of a particular area should be the first action carried out in the tourism planning process [9]. Tourism potential refers to the ability of a particular location to attract and receive tourists and to be attractive to tourists [7]. Tourism potential is defined as the sum of resources possessed by a particular local community that can be transformed into tourism offerings and tourism products [25]. To a large extent, the attractiveness of the local community is determined by climate, hydrographic objects, flora, fauna, and landscape [26]. All this affects the tourism potential. If a rural settlement has an attractive tourism offer, it has greater tourism potential and vice versa. Attractiveness of the tourism offer is a term that refers to the tourism potential [7] and is one of the most important factors for determining tourism potential.

The tourism potential also depends on investments in hotels, restaurants, and other tourist facilities, and it is necessary to connect tourism with other branches of the economy [27]. To determine the tourism potential, it is necessary to include other factors, not only available resources. Operational factors in tourism are also a problem when determining tourism potential [7]. If a local community has potential resources for tourism development, it does not mean that they will be used. Tourism potential can be realized only when the tourist image of that local community is created, when problems are solved in terms of policy, investment, and coordination with other activities [28].

To use the tourism potentials and realize the competitive advantages of a certain tourist location, it is necessary the offered tourist experience to be more attractive than other tourist locations [29]. Each local community has certain tourism potentials, but this potential needs to be identified and determined on which to build the tourist offer of that local community. To build a tourist offer using tourist potential, it is first necessary to identify the attractiveness of this location for tourists. When tourists are faced with the complexity of choosing tourist offers, they will choose the one that has better resources whose offer is more attractive to them [15]. To succeed in the market, it is necessary to strategically assess and manage their attractiveness in order to make it more attractive than competing locations [8].

Therefore, the right information about tourism potential will contribute to development of the local community because it will be possible to use the human and social capital of the area, and residents will make certain profits and improve the living standards of the population in the area [30]. Based on that, in order to build the tourism offer, it is necessary to determine the tourism potential and determine the attractiveness of that location for tourists.

\subsection{Multicriteria Approach in the Examination of Tourism Potential}

To determine the tourism potential of a certain tourist location, it is necessary to apply an interdisciplinary approach and include various criteria by which it would be evaluated. Due to the existence of several criteria according to which the examination of tourism potential is performed, the MCDA methods were used in this study. The use of MCDA methods in tourism is widely accepted and various methods have been used.

Liaghat et al. [31] used the AHP method to investigate which location in Malaysia has the best tourism potential for building a tourist resort. Zhou et al. [32] used the hybrid AHP method to assess the competitiveness of individual tourist destinations in West Virginia. Wang et al. [33] used the fuzzy comprehensive evaluation method and the AHP method to assess the tourism potential of Hongshan Zoo in China. Do and Chen [34] applied 
fuzzy AHP (FAHP) to determine the weight of criteria and sub-criteria of tourism potential in Vietnam. Oh, et al. [35] took the Delphi and AHP methods to assess the interstate competitiveness of tourist destinations to determine the tourism potential.

Lin and Lu [36] combined the fuzzy Delphi method together with the fuzzy ANP (FANP) method to determine the tourism potentials of sustainable ecotourism at Yangshan Ecological Park in Kinmen. Peng and Tzeng [37] used a hybrid-modified multiple attribute decision-making (MADM), based applying the decision-making trial and evaluation laboratory (DEMATEL) technique to build network relationship maps and to determine weights using the ANP method together with the target Multi-Criteria Optimization and Compromise Solution (VIKOR) built a model for determining the tourist potential and improving industrial heritage tourism.

Zhang et al. [38] used TOPSIS and entropy methods to assess the competitiveness of tourism potentials of the Yangtze River Delta region in China. Ilban and Yildırım [39] measured tourism potential in 15 countries using the TOPSIS method. Botti and Peypoch [40] applied the ELimination and Choice Expressing REality (ELECTRE) method to examine the potential of tourist destinations to strengthen competitiveness in Hawaii. Huang and Peng [41] developed the Fuzzy Rasch model to examine the tourism potential of destination competitiveness in nine Asian countries using the TOPSIS method. Lopes et al. [42], based on the method of The Preference Ranking Organization METHod for Enrichment of Evaluations (PROMETHEE), and examined the competitiveness of tourist destinations in determining the tourism potential in Portugal.

Ullah, et al. [2] examined Pakistan's tourism coastal potentials using a checklist of grouped physical and human factors observed through weighted parameters of the fuzzy logical decision matrix. Zhu et al. [43] conducted the multi-hierarchy evaluation model (MHEM) and the entropy method to determine the weight of criteria to determine the tourism potential and attractiveness of 16 cities within the Yangtze River Delta in China. Carayannis, et al. [44] used the Measuring attractiveness through a categorical-based evaluation (MACBETH) technique method to create a consistent tourism destination rating index to improve the competitiveness of tourism potentials in Portugal. Puška et al. [22] combined the methods Additive Ratio ASsessment (ARAS), CRiteria Importance Through Intercriteria Correlation (CRITIC) and Full Consistency Method (FUCOM) to examine the sustainable rural tourism potential in Brčko District. Based on the review of works, it can be concluded that MCDA methods can be used in determining the tourist potential.

\subsection{Rural Tourism Potential of Brčko District}

The existing and potential tourism offer affects development of rural areas. Rural tourism is experiencing increasing demand in many developed and developing countries [33]. Brčko District has an area of $494.96 \mathrm{~km}^{2}$, of which $95 \%$ of the total territory falls under the rural area [15]. Therefore, development of tourism in these areas needs to be based on rural tourism. Brčko District area provides an opportunity for improvement and development of the following types of tourism that can be represented in rural areas: hunting tourism, excursion, mountain, ecological, agritourism, cultural, spa, event, historical, religious tourism and gastronomic tourism. This is due to the favorable geographical position and natural conditions available in Brčko District.

Brčko District is located in northeastern Bosnia and Herzegovina (Figure 1). The geographical position of Brčko District is very favorable, and it is necessary to use this position for development of tourism. This area abounds in various possibilities due to cultural and tourism potentials. With its specificity, diversity, rich history, and tradition, Brčko District has great tourism potentials, but these potentials have not been used in an adequate way. Thus, it is necessary to turn these potentials into a tourism product. Therefore, in cooperation with the Government of Brčko District, an assessment of rural tourism potentials was made to develop these rural areas. Applying this approach, it is possible to assess the rural tourism potential in other parts of Bosnia and Herzegovina and thus improve rural tourism in this country. 


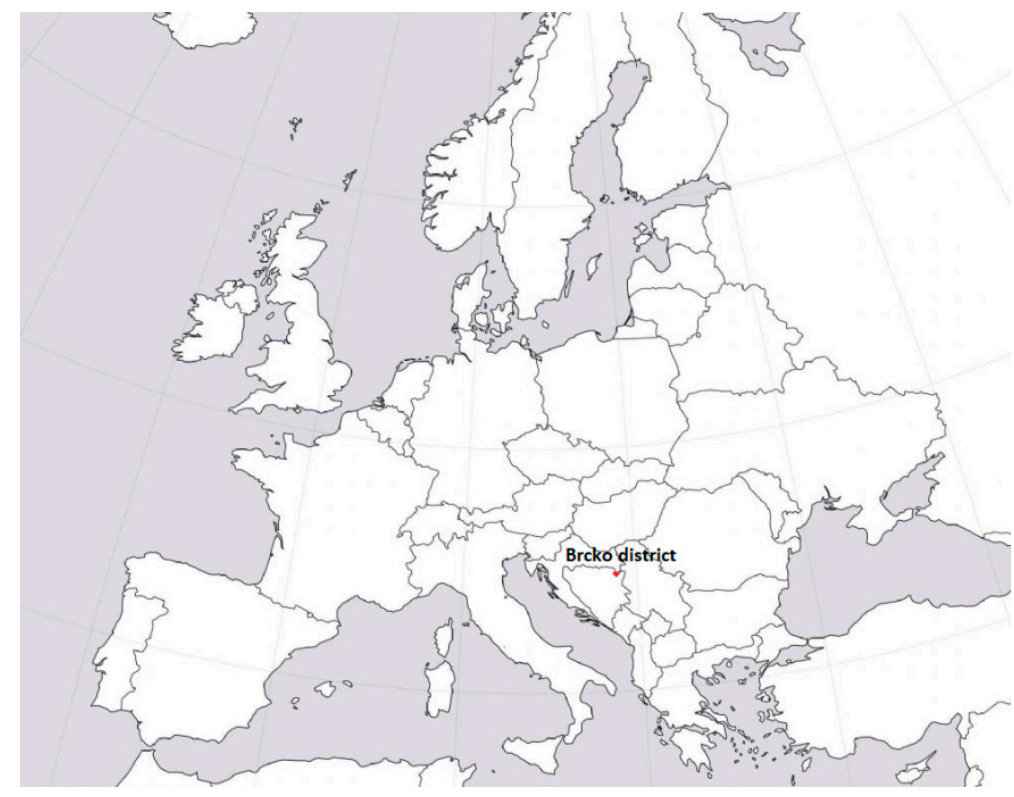

Figure 1. Location of Brčko District.

In the rural areas of Brčko District, the number of events of different character based on historical, cultural, and religious heritage is increasing. The area of Brčko District has potential opportunities for rural tourism as a supplementary activity, because in addition to regular agricultural activities, tourists can be provided with the activities and events focused on the promotion of tradition, gastronomy, and customs. According to Đurić and Ćejvanović [45], development of rural tourism in Brčko District should be based on: recreational and educational facilities, sports and recreational facilities and gastronomic offer. The territory of Brčko District has ideal conditions for growing some types of fruit, and some of the specific types of tourism could be developed [46] such as wine tourism or gastronomic tourism. Gastronomic (food) tourism is often a tool for the sustainability of rural areas [47].

Rural tourism is associated with ecotourism, cultural tourism and agritourism [48] and it is necessary to examine all factors that affect development of rural tourism potential. The rural areas of Brčko District have certain potential for development of these types of tourism and have natural resources, multiethnic cultural tradition, and ideal conditions for growing certain varieties of fruit as well as for growing other agronomic species. Based on that, it can be concluded that there are real conditions for development of rural tourism in Brčko District. It is necessary to investigate the potential for development of rural tourism in Brčko District. Six rural settlements in Brčko District were used in this study.

Gornji Zovik (A1) is located in the southeastern part of Brčko District. This rural settlement has a variety of natural resources. Above this settlement is the Granaš elevation, which offers the possibility of mountain tourism. Nearby is the Wedding Cemetery, with twenty-nine "stećak" tombstones [15]. In this settlement, "Zovicko ljeto" and "Dani zove" are organized on an annual basis. Razljevo (A2) is located in the eastern part of Brčko District. In this village there is a traditional house which is equipped with traditional objects. Every year there is a traditional fair, folklore festival and traditional cauldron festival (gastronomic competition). The Šutica mill is located near Ražljevo.

Maoča (A5) is located in the southern part of Brčko District below the Majevica Mountain. The building of the Nožinaga mosque and the Dovište site are well known by their tradition where prayers for rain during dry days are performed. The area above Maoča is attractive for mountain tourism. The traditional manifestation "Trešnjarevo" is held in this village annually. Bijela (A6) is located at the confluence of the rivers the Bijeli Potok and the Tinja. There are two old mills in this settlement. The Beg Tower National Monument is very famous. Above Bijela, the forest slopes rise where Katina Cave and 
Dark Cave are located. Above Bijela is the hill Kukavičluk and this terrain is attractive for mountain tourism [22].

\section{Research Methodology}

The methodological framework for the assessment of rural tourism potentials was implemented through three phases (Table 1).

Table 1. Research methodology.

\begin{tabular}{lll}
\hline Research Phases & Research Steps \\
\hline \multirow{2}{*}{ Research phase } & - & Decision on research of rural tourist potential in Brčko District \\
& - & Appointment of experts \\
& - & Selection of criteria for determining rural tourism potential \\
Determining weight criteria and & - & Determining a sample of 6 rural settlements \\
evaluating alternatives & - & Forming a survey questionnaire \\
& - & Assessment of weight criteria by experts \\
& - & Assessment of rural tourism potentials by experts \\
Ranking alternatives & - & Creating an initial decision matrix \\
& - & Application of the FUCOM method in determining the weighting criteria \\
& - & Application of the fuzzy MARCOS method in ranking of alternatives \\
\end{tabular}

The first phase was the research phase. At this stage, a decision was made to assess the rural tourism potential in Brčko District. The assessment of the rural tourist potential was done in cooperation with the Government of Brčko District of Bosnia and Herzegovina. According to their developmental strategy, the focus is on strengthening agriculture, economy, and tourism. Since 95\% of Brčko District's area is rural, it was necessary to assess the tourism potential of the area, to provide guidelines for improving tourism in Brčko District. Expert decision-making was used in this research. In cooperation with the Brčko District Government and their Department of Tourism, potential experts were identified. As criteria for the selection of these experts, we used their experience in the field of rural tourism, knowledge of rural areas of Brčko District and the possibility of participating in this research, due to the situation caused by the COVID-19 virus. From the total number of experts proposed by the Department of Tourism, three experts were selected to assess the rural tourism potential. The first expert (DM1) was selected in the field of rural development, the second (DM2) and the third expert (DM3) were selected in the field of tourism. All selected experts have many years of experience and have worked on several projects in the field of tourism. After the experts were selected, the criteria and alternatives to be used in this research were selected. This was done by applying panel research. First, a desk research was performed analyzing previous works to identify the criteria to be used in this study. These are the following papers: Do and Chen [34], Zhou [18], Zhou, et al. [32], Mikulić, et al. [49], Topolansky Barbe, et al. [29], Peng and Tzeng [37], Yan et al. [7] and Puška et al. [22]. Four main criteria were selected: natural resources (C1), culture (C2), social factors (C3) and economic factors (C4) (Table 2). Each of these criteria were broken down into an equal number of sub-criteria.

Once the criteria were determined it was necessary to select the alternatives to be used in this research. A basic set of surveys was formed, including 59 rural settlements. Based on the documents available to the Department of Tourism, the number of rural settlements was first reduced to 14, and these settlements were analyzed in detail. At the end, 6 rural settlements were selected with the best predisposition to perform rural tourism. Six rural settlements form a sample in this study that represent six alternatives, namely: Gornji Zovik (A1), Ražljevo (A2), Brezovo Polje (A3), Grbavica (A4), Maoča (A5) and Bijela (A6). Based on the criteria and alternatives, a research model was formed (Figure 2). In cooperation with the Government of Brčko District, a visit of experts to these areas was organized to determine which tourist resources these areas have at their disposal. As part of the 
visits, the experts conducted interviews with the local population and received additional information on the rural tourism potential of these areas.

Table 2. Criteria for determining rural tourism potential.

\begin{tabular}{|c|c|c|}
\hline Id & Criteria & Description \\
\hline $\mathrm{C}_{1}$ & Natural resources & $\begin{array}{l}\text { represent the totality of geographical characteristics available to a particular } \\
\text { community, which is determined by the climate, aquatic, flora and fauna and } \\
\text { natural heritage of that location. }\end{array}$ \\
\hline $\mathrm{C}_{2}$ & Culture & $\begin{array}{l}\text { represents a set of values, beliefs, behaviors, and symbols such as tradition, } \\
\text { customs, historical monuments, art, etc. which is used as a tourist product. }\end{array}$ \\
\hline$C_{3}$ & Social factors & $\begin{array}{l}\text { is the wealth of human resources available to a particular local community and } \\
\text { which relate to age, education, employment, etc. at the local community }\end{array}$ \\
\hline $\mathrm{C}_{4}$ & Economic factors & $\begin{array}{l}\text { are the economic resources of a certain local community and concern the } \\
\text { existing economic infrastructure and the existence of domestic products that } \\
\text { are attractive to tourists }\end{array}$ \\
\hline
\end{tabular}

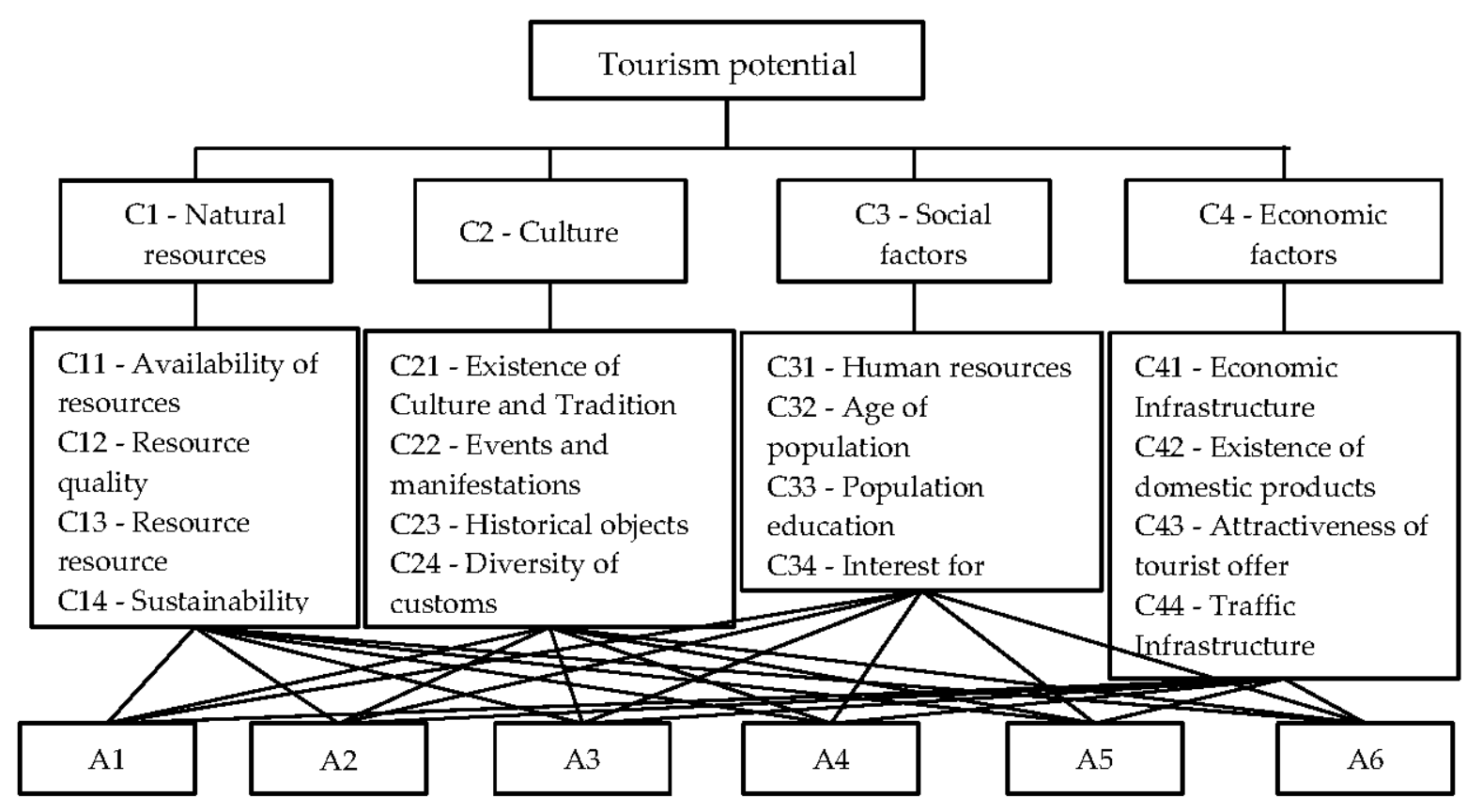

Figure 2. Model of tourist potential.

The second phase of the research dealt with determination of the weight of the criteria and the evaluation of alternatives by experts. When the criteria and alternatives were selected, a survey questionnaire was created based on these activities. The survey questionnaire consisted of two parts. The first part of the survey questionnaire was intended to assess the weights of criteria and sub-criteria. The second part of the survey questionnaire was intended to assess alternatives. The first part of the questionnaire was filled out by the experts. First, they ranked the criteria or sub-criteria according to the importance that they perceived. Then the criterion that has the greatest significance was assigned a value of 1 , while the other criteria were assigned a value up to 9, with the proviso that it is possible to give values with a decimal number. The higher the value of a particular criterion, the less important it is. The second part of the questionnaire was completed by the experts by providing linguistic values for certain alternatives ranging from very poor (VP) to very good (VG), using a seven-point scale (Table 3). After the data were collected from the experts, an initial decision matrix was formed. The initial decision matrix was the first step in applying the MCDA method. 
Table 3. Criteria for determining rural tourism potential.

\begin{tabular}{cc}
\hline Linguistic Variable & Fuzzy Numbers \\
\hline Very poor (VP) & $(0,0,1)$ \\
Poor (P) & $(0,1,3)$ \\
Medium poor (MP) & $(1,3,5)$ \\
Medium (M) & $(3,5,7)$ \\
Medium good (MG) & $(5,7,9)$ \\
Good (G) & $(7,9,10)$ \\
Very good (VG) & $(9,10,10)$ \\
\hline
\end{tabular}

The third phase of the research was concerned with ranking of alternatives. Before ranking alternatives, it was necessary to determine the weights of the criteria using the FUCOM method. The reason for using the FUCOM method to determine the weight of the criteria is because this method has certain advantages over other methods used from the aspect of expert examination [50]. The experts only needed to assign a value of 1 to the criterion that is most important in their opinion, while the other criteria are assigned a value of up to 9 depending on the importance of that criterion for experts. The greater the importance of a criterion, the closer the value for that criterion will be to 1 and vice versa. This has simplified the collection of data by experts. The steps of the FUCOM method are presented in the next subsection. Once the weights of the criteria were determined, the alternatives were ranked using the fuzzy Measurement Alternatives and Ranking according to the COmpromise Solution (MARCOS) method. The reason the fuzzy approach was applied one can be found in the fact that the values for evaluating alternatives were presented in the form of linguistic values. Therefore, it was necessary to apply the fuzzy version of the MARCOS method. The fuzzy MARCOS method is just one of several methods that could be used as the primary method in the research. The reason why the fuzzy MARCOS method was chosen, and no other methods, is that through the application so far, this method has shown that its results are concisions from other methods [51]. However, the results given by this method are compared with the results given by other fuzzy methods, and thus the results given by this method will be confirmed or refuted. The steps of the fuzzy MARCOS method are presented in the next subsection. After the ranking of the alternatives was determined, the obtained results were examined. The results obtained using the fuzzy MARCOS method were first compared with other selected methods, and then the sensitivity of the ranking of alternatives to changes in the weight of the criteria was performed.

\subsection{FUCOM (FUll COnsistency Method) Method}

The FUCOM method was developed by Pamučar, et al. [50]. The FUCOM method is used to determine the weight of the criteria. The FUCOM method compares established criteria in pairs and performs the validation of results by deviating from the maximum consistency [51]. Using this method subjectivity in the decision-making process is reduced [52]. This method, in relation to other methods for determining the subjective weights of criteria, has the main advantages: reduced number of pairs to compare, consistency in comparing criteria and contributing to rational judgment [53].

The FUCOM method is implemented using the following steps [50]:

Step 1. Ranking of criteria/sub-criteria using expert evaluation.

Step 2. Determining the vector of comparative significance of the evaluation criteria.

Step 3. Defining the constraints of a nonlinear optimization model. The values of the weighting coefficients should satisfy two conditions, namely [54]:

Condition 1 . The ratio of weight coefficients is equal to the comparative significance between the observed, the condition is met when: $w_{k} / w_{k+1}=\varphi_{k /(k+1)}$ Condition 2 . The final values of the weighted coefficients should satisfy the condition of mathematical transitivity, i.e., $\varphi_{k /(k+1)} \times \varphi_{(k+1) /(k+2)=\varphi_{k /(k+2)}}$ 
Step 4. Defining a model for determining the final values of the weighting coefficients of the criteria [55].

Step 5. Step 5. Solving the model and obtaining the final weight of the criteria/sub-criteria $\left(w_{1}, w_{2}, \ldots, w_{n}\right)^{T}$

\subsection{Fuzzy Measurement of Alternatives and Ranking According to COmpromise Solution (MARCOS) Method}

The MARCOS method was developed by the authors Stević, et al. [56]. The MARCOS method uses a defined relationship between alternatives and the reference values of those alternatives that represent ideal and anti-ideal solutions. Determining the final order using the MARCOS method is done based on the utility function [57]. The value of the utility function of the alternative is obtained in relation to the ideal and anti-ideal solution. The best alternative is the one that is closest to the ideal solution and at the same time the furthest from the anti-ideal solution [53]. The Fuzzy MARCOS method consists of the following steps [58]:

Step 1. Forming an initial fuzzy decision matrix.

Step 2. Extension of the initial fuzzy decision matrix. In this step, the initial matrix is expanded with the anti-ideal (AAI) and ideal solution (AI). The anti-ideal solution (AAI) is obtained by applying the following expression:

$$
A A I=\min _{j} x_{i j} \text { if } j \in B \text { and } \max _{j} x_{i j} \text { if } j \in C
$$

The ideal solution (AI) is obtained using the following expression:

$$
A I=\max _{j} x_{i j} \text { if } j \in B \text { and } \min _{j} x_{i j} \text { if } j \in C
$$

where $B$ represents benefit criteria that need to be maximized, while $C$ represents cost criteria that need to be minimized [59].

Step 3. Normalizing the initial fuzzy decision matrix. Normalization is performed using the following expressions depending on the criterion in question:

$$
\begin{aligned}
& \widetilde{n}_{i j}=\left(n_{i j}^{l}, n_{i j}^{m}, n_{i j}^{u}\right)=\left(\frac{x_{i d}^{l}}{x_{i j}^{u}}, \frac{x_{i d}^{l}}{x_{i j}^{m}}, \frac{x_{i d}^{l}}{x_{i j}^{l}}\right) \text { if } j \in C \\
& \widetilde{n}_{i j}=\left(n_{i j}^{l}, n_{i j}^{m}, n_{i j}^{u}\right)=\left(\frac{x_{i j}^{l}}{x_{i d}^{u}}, \frac{x_{i j}^{m}}{x_{i d}^{u}}, \frac{x_{i j}^{u}}{x_{i d}^{u}}\right) \text { if } j \in B
\end{aligned}
$$

where $l$ is the first fuzzy number, $m$ is the second fuzzy number and $u$ is the third fuzzy number.

Step 4. Aggravation normalized decision matrix. The aggravation of the normalized decision matrix is done using the following expression:

$$
\widetilde{v}_{i j}=\left(v_{i j}^{l}, v_{i j}^{m}, v_{i j}^{u}\right)=\widetilde{n}_{i j} \otimes \widetilde{w}_{j}=\left(n_{i j}^{l} \times w_{j}^{l}, n_{i j}^{m} \times w_{j}^{m}, n_{i j}^{u} \times w_{j}^{u}\right)
$$

Step 5. The calculation of Si matrix implies the sum of the values by the alternatives including the anti-ideal and ideal solution by the following expression:

$$
\widetilde{S}_{i}=\sum_{i=1}^{n} \widetilde{v}_{i j}
$$


Step 6. Calculation of the degree of usefulness of Ki in relation to the anti-ideal and ideal solution using the following expression:

$$
\begin{gathered}
\widetilde{K}_{i}^{-}=\frac{\widetilde{S}_{i}}{\widetilde{S}_{a i}}=\left(\frac{s_{i}^{l}}{s_{a i}^{u}}, \frac{s_{i}^{m}}{s_{a i}^{m}}, \frac{s_{i}^{u}}{s_{a i}^{l}}\right) \\
\widetilde{K}_{i}^{+}=\frac{\widetilde{S}_{i}}{\widetilde{S}_{i d}}=\left(\frac{s_{i}^{l}}{s_{i d}^{u}}, \frac{s_{i}^{m}}{s_{i d}^{m}}, \frac{s_{i}^{u}}{s_{i d}^{l}}\right)
\end{gathered}
$$

Step 7. Calculation of the fuzzy matrix $\widetilde{T}_{i}$ using the following expression:

$$
\widetilde{T}_{i}=\widetilde{t}_{i}=\left(t_{i}^{l}, t_{i}^{m}, t_{i}^{u}\right)=\widetilde{K}_{i}^{-} \oplus \widetilde{K}_{i}^{+}=\left(k_{i}^{-l}+k_{i}^{+l}, k_{i}^{-m}+k_{i}^{+m}, k_{i}^{-u}+k_{i}^{+u}\right)
$$

Determining the fuzzy number $\widetilde{D}$ using the following expression:

$$
\widetilde{D}=\left(d^{l}, d^{m}, d^{u}\right)=\max _{i} \widetilde{t}_{i j}
$$

Step 8. De-fuzzify of fuzzy numbers using the following expression:

$$
d f_{\text {crisp }}=\frac{l+4 m+u}{6}
$$

Step 9. Determining the utility function $f\left(\widetilde{K}_{i}\right)$ through the aggregation of utility functions according to the anti-ideal solution (a) and the ideal solution (b).

- Utility function according to the anti-ideal solution

$$
f\left(\widetilde{K}_{i}^{+}\right)=\frac{\widetilde{K}_{i}^{-}}{d f_{\text {crisp }}}=\left(\frac{k_{i}^{-l}}{d f_{\text {crisp }}}, \frac{k_{i}^{-m}}{d f_{\text {crisp }}}, \frac{k_{i}^{-u}}{d f_{\text {crisp }}}\right)
$$

- Utility function according to the ideal solution

$$
f\left(\widetilde{K}_{i}^{-}\right)=\frac{\widetilde{K}_{i}^{+}}{d f_{\text {crisp }}}=\left(\frac{k_{i}^{+l}}{d f_{\text {crisp }}}, \frac{k_{i}^{+m}}{d f_{\text {crisp }}}, \frac{k_{i}^{+u}}{d f_{\text {crisp }}}\right)
$$

Step 10. Calculation of the final utility function:

$$
f\left(K_{i}\right)=\frac{K_{i}^{+}+K_{i}^{-}}{1+\frac{1-f\left(K_{i}^{+}\right)}{f\left(K_{i}^{+}\right)}+\frac{1-f\left(K_{i}^{-}\right)}{f\left(K_{i}^{-}\right)}} ;
$$

Step 11. Ranking alternatives. The best alternative is the one with the highest value, while the worst is the alternative with the lowest value.

\section{Results}

Before evaluating the alternatives used in the research, the weights of the criteria were determined. The weights of the criteria and sub-criteria were performed by filling in the first part of the survey questionnaire by experts. The experts first determined the weights for the main criteria and then for the sub-criteria. When evaluating the main criteria, experts 2 and 3 gave the greatest importance to criterion $C 1$, while expert 1 gave the greatest importance to criterion C3. Other criteria were ranked, and their values determined (Table 4). 
Table 4. Assessment of weights of main criteria.

\begin{tabular}{ccccc}
\hline Expert 1 & $\mathrm{C} 3$ & $\mathrm{C} 4$ & $\mathrm{C} 1$ & $\mathrm{C} 2$ \\
$\mathrm{C} 3$ (best criterion) & 1 & 1.8 & 2.0 & 2.6 \\
\hline Expert 2 & $\mathrm{C} 1$ & $\mathrm{C} 2$ & $\mathrm{C} 3$ & $\mathrm{C} 4$ \\
$\mathrm{C} 1$ (best criterion) & 1 & 1.2 & 1.3 & 1.3 \\
\hline Expert 3 & $\mathrm{C} 1$ & $\mathrm{C} 2$ & $\mathrm{C} 3$ & $\mathrm{C} 4$ \\
$\mathrm{C} 1$ (best criterion) & 1 & 1 & 1.2 & 1.5 \\
\hline
\end{tabular}

By applying the steps of the FUCOM method, weights were obtained based on the evaluation of individual experts (Table 5). By applying the arithmetic mean, the final weights of the criteria were obtained. Criterion $\mathrm{C} 1$ is of the greatest importance for experts, followed by criterion $\mathrm{C} 3$ and criterion $\mathrm{C} 4$. Based on the obtained results of the weight of the main criteria, it can be concluded that criteria $\mathrm{C} 1$ and $\mathrm{C} 3$ have similar importance while criteria C2 and C4 have less importance compared to the first two criteria.

Table 5. Criteria weight values.

\begin{tabular}{ccccc}
\hline \multirow{2}{*}{ Expert 1 } & $\mathrm{C} 1$ & $\mathrm{C} 2$ & $\mathrm{C} 3$ & $\mathrm{C} 4$ \\
& 0.2299 & 0.2117 & 0.3218 & 0.2366 \\
\hline \multirow{2}{*}{ Expert 2 } & $\mathrm{C} 1$ & $\mathrm{C} 2$ & $\mathrm{C} 3$ & $\mathrm{C} 4$ \\
& 0.2947 & 0.2376 & 0.2339 & 0.2339 \\
\hline \multirow{2}{*}{ Expert 3 } & $\mathrm{C} 1$ & $\mathrm{C} 2$ & $\mathrm{C} 3$ & $\mathrm{C} 4$ \\
& 0.2689 & 0.2689 & 0.2366 & 0.2256 \\
\hline \multirow{2}{*}{ Final weights } & $\mathrm{C} 1$ & $\mathrm{C} 2$ & $\mathrm{C} 3$ & $\mathrm{C} 4$ \\
& 0.2645 & 0.2394 & 0.2641 & 0.2320 \\
\hline
\end{tabular}

After determining the weights of the criteria, the experts determined the weights of the sub-criteria in the same way. They first determined which sub-criterion is the most important in their opinion and ranked the other criteria according to importance. Then, they determined the vector of comparative significance of these sub-criteria. Using the steps of the FUCOM method, the weights of all the criteria for each expert were established and the final weights were determined using the arithmetic mean (Table 6). Sub-criterion C12 has the greatest importance in criterion $\mathrm{C} 1$, sub-criterion $\mathrm{C} 21$ has the greatest importance in criterion $\mathrm{C} 2$, sub-criterion $\mathrm{C} 34$ has the greatest importance in criterion $\mathrm{C} 3$, while subcriterion $\mathrm{C} 43$ has the greatest importance in criterion $\mathrm{C} 4$.

Table 6. Weights of sub-criteria based on expert assessment.

\begin{tabular}{|c|c|c|c|c|c|c|c|c|c|}
\hline \multirow{2}{*}{ Expert 1} & $\begin{array}{c}\mathrm{C}_{11} \\
0.2378\end{array}$ & $\begin{array}{c}C_{12} \\
0.3043\end{array}$ & $\begin{array}{c}C_{13} \\
0.2341\end{array}$ & $\begin{array}{c}C_{14} \\
0.2238\end{array}$ & \multirow{2}{*}{ Expert 1} & $\begin{array}{c}C_{21} \\
0.3043\end{array}$ & $\begin{array}{c}C_{22} \\
0.2238\end{array}$ & $\begin{array}{c}C_{23} \\
0.2378\end{array}$ & $\begin{array}{c}\mathrm{C}_{24} \\
0.2341\end{array}$ \\
\hline & $\begin{array}{c}C_{31} \\
0.2355\end{array}$ & $\begin{array}{c}C_{32} \\
0.2252\end{array}$ & $\begin{array}{c}C_{33} \\
0.2285\end{array}$ & $\begin{array}{c}C_{34} \\
0.3108\end{array}$ & & $\begin{array}{c}C_{41} \\
0.2439\end{array}$ & $\begin{array}{c}C_{42} \\
0.2293\end{array}$ & $\begin{array}{c}\mathrm{C}_{43} \\
0.3073\end{array}$ & $\begin{array}{c}\mathrm{C}_{44} \\
0.2195\end{array}$ \\
\hline \multirow{2}{*}{ Expert 2} & $\begin{array}{c}\mathrm{C}_{11} \\
0.2171\end{array}$ & $\begin{array}{c}C_{12} \\
0.3040\end{array}$ & $\begin{array}{c}C_{13} \\
0.2451\end{array}$ & $\begin{array}{c}\mathrm{C}_{14} \\
0.2338\end{array}$ & \multirow{2}{*}{ Expert 2} & $\begin{array}{c}C_{21} \\
0.2356\end{array}$ & $\begin{array}{c}C_{22} \\
0.2283\end{array}$ & $\begin{array}{c}C_{23} \\
0.2968\end{array}$ & $\begin{array}{c}C_{24} \\
0.2394\end{array}$ \\
\hline & $\begin{array}{c}C_{31} \\
0.2394 \\
\end{array}$ & $\begin{array}{c}C_{32} \\
0.2356 \\
\end{array}$ & $\begin{array}{c}C_{33} \\
0.2283 \\
\end{array}$ & $\begin{array}{c}C_{34} \\
0.2968 \\
\end{array}$ & & $\begin{array}{c}\mathrm{C}_{41} \\
0.2254 \\
\end{array}$ & $\begin{array}{c}\mathrm{C}_{42} \\
0.2428 \\
\end{array}$ & $\begin{array}{c}C_{43} \\
0.3156 \\
\end{array}$ & $\begin{array}{c}\mathrm{C}_{44} \\
0.2162\end{array}$ \\
\hline \multirow{2}{*}{ Expert 3} & $\begin{array}{c}C_{11} \\
0.2366\end{array}$ & $\begin{array}{c}C_{12} \\
0.3076\end{array}$ & $\begin{array}{c}C_{13} \\
0.2229\end{array}$ & $\begin{array}{c}C_{14} \\
0.2330\end{array}$ & \multirow{2}{*}{ Expert 3} & $\begin{array}{c}C_{21} \\
0.2402\end{array}$ & $\begin{array}{c}C_{22} \\
0.3074\end{array}$ & $\begin{array}{c}C_{23} \\
0.2329\end{array}$ & $\begin{array}{c}C_{24} \\
0.2196\end{array}$ \\
\hline & $\begin{array}{c}C_{31} \\
0.2298\end{array}$ & $\begin{array}{c}C_{32} \\
0.2298\end{array}$ & $\begin{array}{c}C_{33} \\
0.2370\end{array}$ & $\begin{array}{c}C_{34} \\
0.3034\end{array}$ & & $\begin{array}{c}\mathrm{C}_{41} \\
0.2387\end{array}$ & $\begin{array}{c}C_{42} \\
0.2161\end{array}$ & $\begin{array}{c}C_{43} \\
0.3199\end{array}$ & $\begin{array}{c}C_{44} \\
0.2253\end{array}$ \\
\hline \multirow{2}{*}{$\begin{array}{c}\text { Final } \\
\text { weights }\end{array}$} & $\begin{array}{c}C_{11} \\
0.2305\end{array}$ & $\begin{array}{c}C_{12} \\
0.3053\end{array}$ & $\begin{array}{c}C_{13} \\
0.2340\end{array}$ & $\begin{array}{c}C_{14} \\
0.2302\end{array}$ & \multirow{2}{*}{$\begin{array}{c}\text { Final } \\
\text { weights }\end{array}$} & $\begin{array}{c}C_{21} \\
0.2600\end{array}$ & $\begin{array}{c}C_{22} \\
0.2532\end{array}$ & $\begin{array}{c}C_{23} \\
0.2558\end{array}$ & $\begin{array}{c}\mathrm{C}_{24} \\
0.2310\end{array}$ \\
\hline & $\begin{array}{c}C_{31} \\
0.2349\end{array}$ & $\begin{array}{c}C_{32} \\
0.2302\end{array}$ & $\begin{array}{c}C_{33} \\
0.2313\end{array}$ & $\begin{array}{c}\mathrm{C}_{34} \\
0.3037\end{array}$ & & $\begin{array}{c}C_{41} \\
0.2360\end{array}$ & $\begin{array}{c}\mathrm{C}_{42} \\
0.2294\end{array}$ & $\begin{array}{c}\mathrm{C}_{43} \\
0.3143\end{array}$ & $\begin{array}{c}C_{44} \\
0.2203\end{array}$ \\
\hline
\end{tabular}


After determining the importance of certain criteria and sub-criteria, the experts evaluated the rural settlements in Brčko District that were taken as alternatives. Experts assessed rural settlements using linguistic values (Table 7). Since the estimates of rural settlements are given in the form of linguistic values, it was necessary to transform them into numerical values using the affiliation function (Table 4). After this step, the experts' assessments were harmonized by applying the arithmetic mean. In this way, a collective decision matrix was formed, which is the first step in the implementation of MCDA methods. The second step in applying the fuzzy MARCOS method was to expand the initial decision matrix with ideal and anti-ideal solutions (expressions 1 and 2). The third step was to normalize the initial decision matrix. Since all criteria and sub-criteria are of the benefit type, expression 3 was used. The fourth step of the fuzzy MARCOS method was to make the normalized extended decision matrix difficult. In this step, the values of the normalized decision matrix were multiplied by the corresponding weights.

Table 7. Assessment of tourist potential of rural settlements in Brčko District.

\begin{tabular}{|c|c|c|c|c|c|c|c|c|c|c|c|c|c|c|c|c|}
\hline DM1 & $C_{11}$ & $C_{12}$ & $\mathrm{C}_{13}$ & $\mathrm{C}_{14}$ & $\mathrm{C}_{21}$ & $\mathrm{C}_{22}$ & $\mathrm{C}_{23}$ & $\mathrm{C}_{24}$ & $C_{31}$ & $\mathrm{C}_{32}$ & $\mathrm{C}_{33}$ & $C_{34}$ & $\mathrm{C}_{41}$ & $C_{42}$ & $\mathrm{C}_{43}$ & $\mathrm{C}_{44}$ \\
\hline A1 & MG & G & MG & $\mathrm{M}$ & MP & $\mathrm{P}$ & MP & MP & $\mathrm{P}$ & $P$ & MP & $P$ & $\mathrm{M}$ & MG & $\mathrm{M}$ & VG \\
\hline A2 & $\mathrm{M}$ & MG & $\mathrm{M}$ & $\mathrm{M}$ & MG & MG & G & MG & $\mathrm{P}$ & $\mathrm{P}$ & MP & MP & G & MG & MG & VG \\
\hline A3 & $\mathrm{M}$ & MG & G & MP & G & MG & G & MG & MP & MP & MP & $\mathrm{P}$ & MG & MG & G & VG \\
\hline A4 & $\mathrm{M}$ & MP & $\mathrm{MP}$ & MP & $\mathrm{M}$ & MP & $\mathrm{MP}$ & $\mathrm{M}$ & $\mathrm{M}$ & MP & MP & MP & MG & $\mathrm{M}$ & $\mathrm{M}$ & VG \\
\hline A5 & $\mathrm{M}$ & MG & MG & MG & $\mathrm{M}$ & MG & MG & VG & MP & $\mathrm{P}$ & MP & $\mathrm{P}$ & MG & $\mathrm{M}$ & MP & $\mathrm{P}$ \\
\hline A6 & MG & $\mathrm{M}$ & $\mathrm{G}$ & MG & VG & G & VG & VG & $\mathrm{M}$ & MP & MP & $\mathrm{M}$ & MG & MG & G & VG \\
\hline DM2 & $C_{11}$ & $C_{12}$ & $\mathrm{C}_{13}$ & $\mathrm{C}_{14}$ & $\mathrm{C}_{21}$ & $\mathrm{C}_{22}$ & $\mathrm{C}_{23}$ & $\mathrm{C}_{24}$ & $C_{31}$ & $\mathrm{C}_{32}$ & $\mathrm{C}_{33}$ & $\mathrm{C}_{34}$ & $\mathrm{C}_{41}$ & $\mathrm{C}_{42}$ & $\mathrm{C}_{43}$ & $\mathrm{C}_{44}$ \\
\hline A1 & MG & MG & G & MG & $\mathrm{M}$ & $\mathrm{M}$ & MG & MG & $P$ & $P$ & MP & MG & MP & $\mathrm{M}$ & MG & $\mathrm{M}$ \\
\hline A2 & $\mathrm{M}$ & MP & $\mathrm{MP}$ & $\mathrm{M}$ & MP & MG & $\mathrm{M}$ & $\mathrm{M}$ & $\mathrm{M}$ & $\mathrm{M}$ & MP & $\mathrm{M}$ & $\mathrm{M}$ & $\mathrm{M}$ & $\mathrm{M}$ & MG \\
\hline A3 & MG & $\mathrm{M}$ & MG & $\mathrm{M}$ & $\mathrm{M}$ & $\mathrm{M}$ & MG & MG & MP & MP & MP & MG & $\mathrm{M}$ & MG & MG & G \\
\hline A4 & MP & MP & $\mathrm{P}$ & MP & MP & MP & $\mathrm{MP}$ & $\mathrm{MP}$ & MP & MP & $\mathrm{M}$ & MP & MG & MG & MP & G \\
\hline A5 & $\mathrm{M}$ & MP & $\mathrm{M}$ & $\mathrm{M}$ & $\mathrm{M}$ & $\mathrm{M}$ & $\mathrm{M}$ & $\mathrm{M}$ & $M$ & $\mathrm{M}$ & MG & MP & MG & $\mathrm{G}$ & $\mathrm{M}$ & MG \\
\hline A6 & MG & MG & MG & $\mathrm{M}$ & MG & $\mathrm{M}$ & G & G & MP & MP & $\mathrm{M}$ & $\mathrm{M}$ & $\mathrm{M}$ & M & MG & G \\
\hline DM3 & $C_{11}$ & $C_{12}$ & $\mathrm{C}_{13}$ & $\mathrm{C}_{14}$ & $\mathrm{C}_{21}$ & $\mathrm{C}_{22}$ & $\mathrm{C}_{23}$ & $\mathrm{C}_{24}$ & $C_{31}$ & $C_{32}$ & $\mathrm{C}_{33}$ & $\mathrm{C}_{34}$ & $\mathrm{C}_{41}$ & $\mathrm{C}_{42}$ & $\mathrm{C}_{43}$ & $\mathrm{C}_{44}$ \\
\hline A1 & MG & MG & G & MG & MG & MG & MG & MG & MP & MP & $\mathrm{M}$ & G & $\mathrm{M}$ & $\mathrm{M}$ & G & $\mathrm{M}$ \\
\hline A2 & $\mathrm{MP}$ & MG & $\mathrm{M}$ & MG & $\mathrm{M}$ & $\mathrm{M}$ & MG & MG & $\mathrm{M}$ & MG & MG & MG & MG & MG & MG & MG \\
\hline A3 & $\mathrm{M}$ & $M$ & MG & $\mathrm{M}$ & $\mathrm{M}$ & MG & MG & $\mathrm{M}$ & $\mathrm{M}$ & $\mathrm{M}$ & $\mathrm{M}$ & $G$ & MG & MG & G & G \\
\hline A4 & $\mathrm{M}$ & $\mathrm{M}$ & $\mathrm{MP}$ & $\mathrm{M}$ & MP & $\mathrm{M}$ & $\mathrm{M}$ & $\mathrm{M}$ & MG & MG & MG & $\mathrm{M}$ & MG & MG & $\mathrm{M}$ & G \\
\hline A5 & $\mathrm{M}$ & $\mathrm{M}$ & MG & $\mathrm{M}$ & $\mathrm{M}$ & MG & MG & $\mathrm{M}$ & MG & $\mathrm{M}$ & MG & $\mathrm{M}$ & MG & MG & MG & $\mathrm{M}$ \\
\hline A6 & MG & $\mathrm{M}$ & MG & $\mathrm{M}$ & M & $\mathrm{M}$ & G & G & $\mathrm{M}$ & $\mathrm{M}$ & M & MG & MG & $\mathrm{M}$ & G & G \\
\hline
\end{tabular}

The fifth step was to calculate the $S_{i}$ matrix to determine the sums of values of the alternatives including the ideal and anti-ideal solution (Table 8). Based on the $S_{i}$ matrix, the utility levels were calculated, which was the step 6 in the fuzzy decision matrix. These degrees of utility were calculated in relation to the anti-ideal and ideal solution. The seventh step of the fuzzy MARCOS method was to calculate the fuzzy matrix $\widetilde{T}_{i}$. This was done by adding the appropriate members of the fuzzy numbers with the degree of usefulness and in relation to the anti-ideal and ideal solution.

Table 8. Calculation of the matrix $S_{i}$, the degree of utility and the fuzzy matrix $\widetilde{T}_{i}$.

\begin{tabular}{|c|c|c|c|c|c|c|}
\hline & $\mathrm{S}_{\mathrm{i}}$ & $\mathbf{K}_{\mathbf{i}}^{-}$ & $\mathrm{K}_{\mathbf{i}}{ }^{+}$ & & $\widetilde{T}_{i}$ & \\
\hline Ideal & 0.590 .811 .00 & 0.591 .001 .70 & 0.911 .971 .93 & & & \\
\hline A1 & 0.400 .610 .83 & 0.400 .761 .41 & 0.621 .501 .60 & & 1.022 .263 .01 & \\
\hline A2 & 0.410 .640 .86 & 0.410 .791 .47 & 0.641 .561 .66 & & 1.052 .353 .13 & \\
\hline A3 & 0.460 .690 .90 & 0.460 .851 .53 & 0.721 .691 .73 & & 1.182 .543 .27 & \\
\hline A4 & 0.300 .530 .75 & 0.300 .651 .28 & 0.461 .291 .45 & & 0.761 .942 .74 & \\
\hline A5 & 0.390 .620 .84 & 0.390 .771 .44 & 0.611 .511 .63 & & 1.012 .283 .07 & \\
\hline A6 & 0.520 .740 .94 & 0.520 .921 .60 & 0.811 .821 .81 & & 1.332 .753 .42 & $d f_{\text {crisp }}$ \\
\hline Anti-ideal & 0.190 .410 .64 & 0.190 .511 .09 & 0.301 .001 .24 & $\max$ & 1.332 .753 .42 & 2.62 \\
\hline
\end{tabular}


To determine the utility function, it was necessary to identify the value of $d f_{\text {crisp }}$ in the step 8 . This value was obtained by determining the maximum values of the fuzzy matrix $\widetilde{T}_{i}$ and by de-fuzzify these maximum values. In step 9 , the utility function was calculated by relating the utility function to the $d f_{\text {crisp }}$ value (Table 9 ). After this step, the utility level and the utility function are de-fuzzify to calculate the final utility function.

Table 9. Calculation of function of the degree of usefulness and de-fuzzify of indicators.

\begin{tabular}{|c|c|c|c|c|c|c|}
\hline Alternative & $f\left(\widetilde{\boldsymbol{K}}_{i}^{-}\right)$ & $f\left(\widetilde{K}_{i}^{+}\right)$ & $d \widetilde{K}_{i}^{-}$ & $d \widetilde{K}_{i}^{+}$ & $d f\left(\widetilde{\boldsymbol{K}}_{i}^{-}\right)$ & $d f\left(\widetilde{K}_{i}^{+}\right)$ \\
\hline A1 & 0.240 .570 .61 & 0.150 .290 .54 & 0.809 & 1.371 & 0.523 & 0.309 \\
\hline $\mathrm{A} 2$ & 0.240 .590 .63 & 0.160 .300 .56 & 0.841 & 1.424 & 0.543 & 0.321 \\
\hline A3 & 0.270 .640 .66 & 0.180 .330 .58 & 0.902 & 1.532 & 0.584 & 0.344 \\
\hline $\mathrm{A} 4$ & 0.180 .490 .55 & 0.110 .250 .49 & 0.699 & 1.179 & 0.450 & 0.267 \\
\hline A5 & 0.230 .580 .62 & 0.150 .290 .55 & 0.816 & 1.380 & 0.526 & 0.311 \\
\hline A6 & 0.310 .700 .69 & 0.200 .350 .61 & 0.970 & 1.653 & 0.630 & 0.370 \\
\hline
\end{tabular}

The step 10 in the fuzzy MARCOS method was to determine the final utility function that was the basis for ranking alternatives. The values obtained by the final utility function represent the final value obtained using the fuzzy MARCOS method (Table 10). The step 11 was applied by ranking the alternatives based on the final utility function.

Table 10. Final reasults.

\begin{tabular}{ccc}
\hline Alternative & $\mathbf{K}_{\mathbf{i}}$ & Rank \\
\hline A1 & 0.525 & 5 \\
A2 & 0.572 & 3 \\
A3 & 0.673 & 2 \\
A4 & 0.378 & 6 \\
A5 & 0.534 & 4 \\
A6 & 0.797 & 1 \\
\hline
\end{tabular}

The results obtained using a combination of FUCOM and fuzzy MARCOS methods and based on expert decision-making have shown that the best rated alternative is A6, followed by alternative A3, while the worst rated alternative is A4. To confirm these results, they were tested.

\section{Examination of Results and Discussion}

\subsection{Examination of Results}

The results were examined within two steps. The first step was focused to examine how other fuzzy methods rank alternatives and whether this ranking order differs from the ranking order obtained using the fuzzy MARCOS method. The second step was to examine how a change in the weight of the sub-criteria affects the ranking of the alternatives.

The first step of testing the research results was performed using five other fuzzy methods: fuzzy Weighted Aggregated Sum Product Assessment (WASPAS), fuzzy Simple Additive Weighting (SAW) technique, fuzzy Multi-Attributive Border Approximation area Comparison (MABAC), fuzzy Additive Ratio Assessment (ARAS) and fuzzy Technique for Order Performance by Similarity to Ideal Solution (TOPSIS). The results obtained (Figure 3) have shown that the results differ within the fuzzy TOPSIS method, where alternatives A1 and A5 replaced the ranking order. Other alternatives have kept the same ranking. Thus, it has been proven that the ranking order obtained by the fuzzy MARCOS method does not differ from the ranking order obtained by applying other fuzzy methods. 


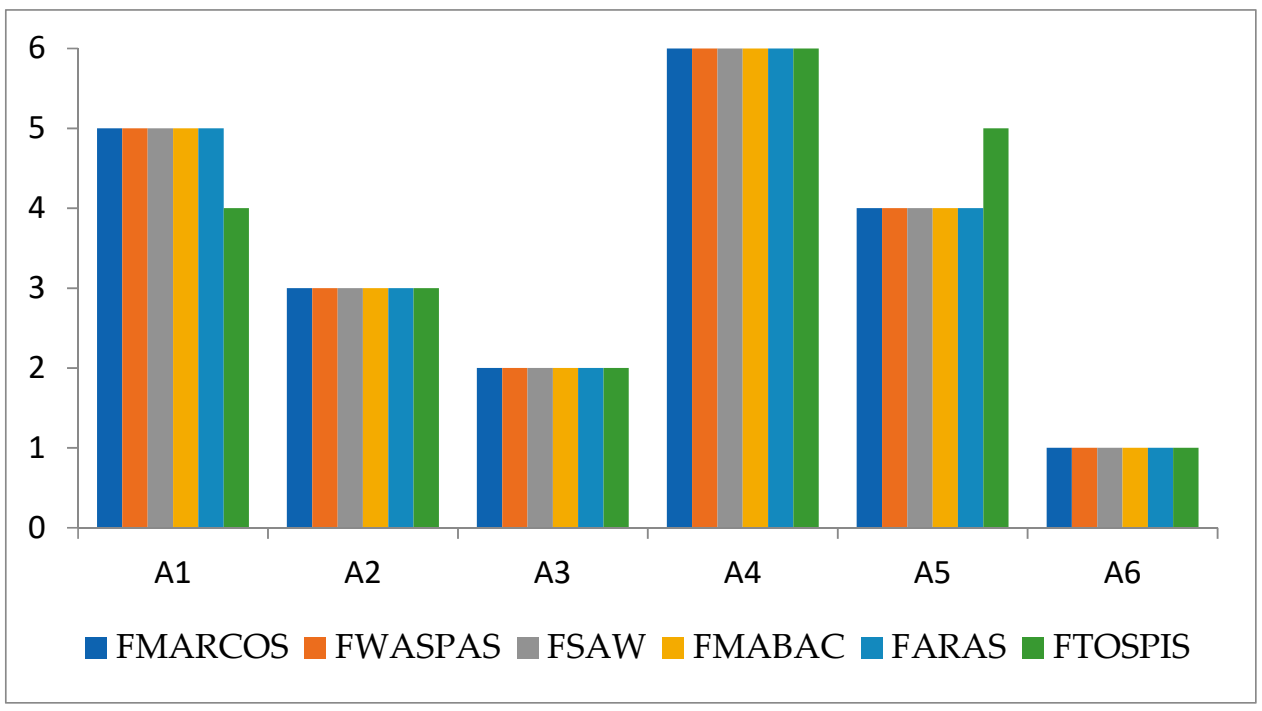

Figure 3. Rank the order of alternatives using different fuzzy methods.

The second step was aimed on sensitivity analysis. In the sensitivity analysis, the results of the research were examined by changing the weights of the sub-criteria and determining how these weights affect the results [60]. Since there are 16 sub-criteria, 17 scenarios were formed (Table 11). The first 16 scenarios gave preference to one of the sub-criteria and this sub-criterion was assigned a weight of 0.25 , while the other criteria were assigned a weight of 0.05 . Thus, this criterion was given a five times advantage over other sub-criteria. In 17 scenarios, all sub-criteria are assigned the same weight $(w=0.0625)$. The results of these scenarios are presented in Figure 4, where the scenarios are presented on the $x$-axis, while the ranked alternative for certain scenarios are presented on the $y$-axis of the figure.

Table 11. Scenarios in sensitivity analysis.

\begin{tabular}{|c|c|c|c|c|c|c|c|c|c|c|c|c|c|c|c|c|}
\hline Scenario & $\mathrm{C}_{11}$ & $\mathrm{C}_{12}$ & $\mathrm{C}_{13}$ & $\mathrm{C}_{14}$ & $\mathrm{C}_{21}$ & $\mathrm{C}_{22}$ & $\mathrm{C}_{23}$ & $\mathrm{C}_{24}$ & $\mathrm{C}_{31}$ & $\mathrm{C}_{32}$ & $\mathrm{C}_{33}$ & $\mathrm{C}_{34}$ & $\mathrm{C}_{41}$ & $\mathrm{C}_{42}$ & $\mathrm{C}_{43}$ & $\mathrm{C}_{44}$ \\
\hline 1 & 0.25 & 0.05 & 0.05 & 0.05 & 0.05 & 0.05 & 0.05 & 0.05 & 0.05 & 0.05 & 0.05 & 0.05 & 0.05 & 0.05 & 0.05 & 0.05 \\
\hline 2 & 0.05 & 0.25 & 0.05 & 0.05 & 0.05 & 0.05 & 0.05 & 0.05 & 0.05 & 0.05 & 0.05 & 0.05 & 0.05 & 0.05 & 0.05 & 0.05 \\
\hline 3 & 0.05 & 0.05 & 0.25 & 0.05 & 0.05 & 0.05 & 0.05 & 0.05 & 0.05 & 0.05 & 0.05 & 0.05 & 0.05 & 0.05 & 0.05 & 0.05 \\
\hline$\vdots$ & $\vdots$ & $\vdots$ & $\vdots$ & $\vdots$ & $\vdots$ & $\vdots$ & $\vdots$ & $\vdots$ & $\vdots$ & $\vdots$ & $\vdots$ & $\vdots$ & $\vdots$ & $\vdots$ & $\vdots$ & $\vdots$ \\
\hline 16 & 0.05 & 0.05 & 0.05 & 0.05 & 0.05 & 0.05 & 0.05 & 0.05 & 0.05 & 0.05 & 0.05 & 0.05 & 0.05 & 0.05 & 0.05 & 0.25 \\
\hline 17 & 0.06 & 0.06 & 0.06 & 0.06 & 0.06 & 0.06 & 0.06 & 0.06 & 0.06 & 0.06 & 0.06 & 0.06 & 0.06 & 0.06 & 0.06 & 0.06 \\
\hline
\end{tabular}

The results of the sensitivity analysis have shown that alternative A6 is insensitive to changes in the weights of the sub-criteria and in all scenarios retained first place in the ranking. Alternative A3 was second in the ranking in 16 scenarios, only in scenario 11 it took the third place in the ranking. Alternative A2 achieved 3rd place in the ranking in 11 scenarios, took 4 th place in the ranking in 4 scenarios, while it took 5 th place in the ranking in 2 scenarios. Alternative A5 took 4th place in 10 scenarios, took second place in one scenario, took third place in 2 scenarios, ranked 5th in three scenarios, and took last place in ranking in scenario 16. Alternative A1 took the fifth place in the ranking of alternatives in 8 scenarios, and took the 3rd, 4th, and 6th place in the ranking of alternatives in three scenarios. In this way, alternatives A5 and A1 have shown the greatest sensitivity to changing the weights of the sub-criteria. Alternative A4 took the last place in the ranking in 13 scenarios, while in 4 scenarios it took the 5th place in the ranking of alternatives. In this way, alternative A4 have shown that it has the worst rural tourist potential of the observed rural settlements in Brčko District, while alternative A6 have shown that it has the best rural tourist potential of all observed rural settlements. 


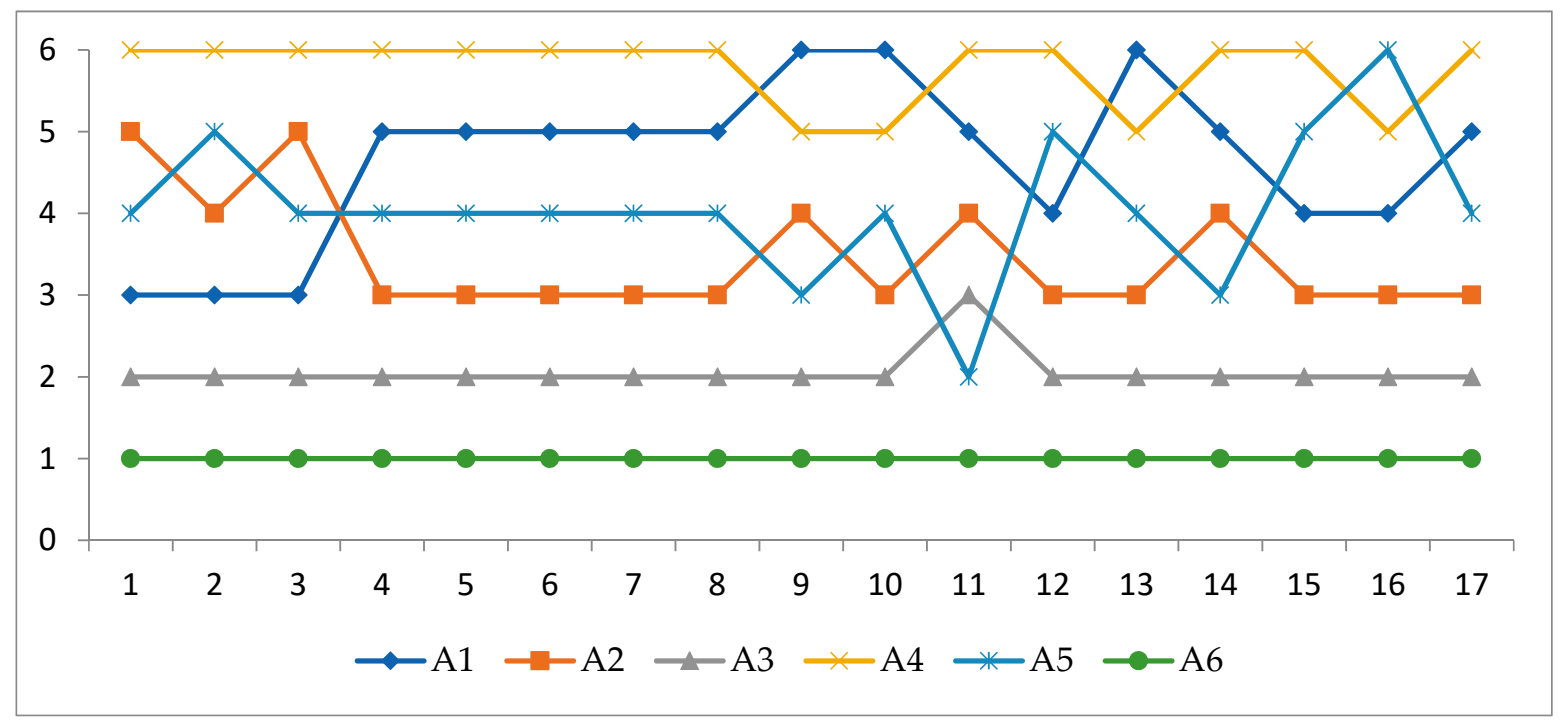

Figure 4. Results of sensitivity analysis.

\subsection{Examination of Results}

This study has introduced the model for determining rural tourism potential using a combination of two MCDA methods, namely FUCOM and fuzzy MARCOS. The results of this decision-making model have shown that the rural settlement of Bijela has the best tourist potential, while the rural settlement of Grbavica has the worst tourist potential among observed settlements based on expert assessments. The assessment of tourism potential was performed based on 4 main criteria and 16 additional criteria. In determining the rural tourism potential, we adjusted the main criteria given by Yan, et al. [7]: natural criteria, culture, social resources, and economic resources. In contrast to this research, cultural and historical potential are combined in this study, while social and economic potentials are separated. The reason for that is due to the specificity of the observed areas.

The area of Bosnia and Herzegovina can boast of natural, cultural, and historical potential, while social and economic resources need to be improved, as shown by expert assessments. Due to the recession present in rural areas [4] and the outflow of population, the decisive factors for the development of tourism in Bosnia and Herzegovina are social resources as well as natural resources available to these areas. In addition, cultural and natural resources are key factors in promoting sustainable development of tourist areas [61]. Based on this, it is necessary to assess rural tourism potential as a multidisciplinary concept and it is necessary to include all factors that may affect the development of tourism.

Economic resources can be influenced and improved through investments in infrastructure, while natural resources and tradition cannot be influenced. Therefore, it is necessary to invest in economic resources through development policies, investments, and coordination of activities [28] to improve the tourism potential of rural settlements in Brčko District. It is necessary to invest in hotels and other tourism facilities [25]. By investing in economic resources, it is possible to improve the conditions prevailing in rural settlements. If the population is provided with better living conditions and a better standard of living, they will remain to live in rural areas. This can improve social resources and improve rural tourism potential.

From the obtained results, Bijela has the best rural tourist potential, while Grbavica has the worst among those observed settlements. To improve rural tourism potential of Brčko District, it is necessary to consider all individual criteria and determine which criteria should be improved by one of the rural settlements to improve these capacities.

Gornji Zovik possesses tourism potential through natural resources and culture, while the shortcomings are social and economic resources. This area has rich natural resources, cultural events are also organized on a regular basis, and this settlement has a lot of his- 
torical buildings. Gornji Zovik needs to invest in tourism through development policy and improve the missing economic resources that need to be built. The settlement of Ražljevo has poor social resources, while its economic resources are the best among observed. Ražljevo needs to use more effectively natural and cultural resources that are at disposal. The settlement of Brezovo Polje has the best indicators in terms of culture, but it has the worst social resources. Grbavica has equally distributed all resources that are not well developed. In this settlement, investment must be done in all resources to improve their tourism potential. The settlement of Maoča, as with other settlements, has low levels of human resources, while other resources are well developed, but more investments must be made in this area to improve their tourism potential. The rural settlement of Bijela has good cultural and historical potential, while there is still more work to be done on social resources.

Based on the previous findings, it can be determined that social potential is missing within all rural settlements. The Brčko District Government must invest in raising people's awareness of tourism. It is necessary to educate people to use the tourism potentials that this territory has at their disposal. It is also necessary to change the political environment to invest more in development of rural areas, where tourism should be one of the basic activities.

This study has shown that the rural tourism potential of Brčko District can be determined using a created model based on MCDA methods. This model has shown what are the real tourism potentials in the observed rural settlements. These results can direct the activities towards the improvement of rural tourism potential in Brčko District. It is also possible through certain modifications to use this model in other branches of tourism and thus get a global picture of the tourism potential of Bosnia and Herzegovina and other countries.

\section{Sustainability Rural Tourism, Emotions, COVID-19 and Values: Future Research}

Numerous researchers [62-67] paid a good deal of attention to emotions in their studies on sustainable tourism and rural tourism. "Three Fs" is the name coined by Holbrook [62] for an experiential approach. This approach focuses on fantasies including dreams, imagination and unconscious desires; feelings involving emotions like love, hate, anger, fear, joy and sorrow and fun consisting of hedonic pleasure coming from playful activities or aesthetic enjoyment. Hence the "three Fs", fantasies, feelings and fun, comprise the key aspects of an experience in consumerism. There is a certain way in which Holbrook [62] analyses social, hedonic and altruistic values. His versions are briefly presented. Social value involves a person's wanting to form the responses of other people by that person's own behaviour when consuming goods and services. Hedonic value is simply the pleasure a person experiences when consuming, constituting the means and the end in itself. Meanwhile fun is the output coming from engaging in leisurely pastimes that are different for different individuals like sports for some or playing music for others. There is aesthetic enjoyment that comes from something a person beholds, whether it be artistic works, recreation or natural, outdoor beauty. Additionally altruistic value derives from selfjustifying endeavours involving awareness of how one's own consumption affects matters, which are often viewed as an end-in-itself like charitable donations. These can be said to be "goodness for the sake of goodness", which is an ethically desirable practice [62]. Other scholars like Chen et al. [63] have investigated "fun" emotions reported by tourists about their memorable experiences and the relationships thereof including pertinent recommendations. The "fun" emotion, i.e., a certain emotional spark and flow, had been positively influenced by hedonism, novelty, meaningfulness, and social interactions, as reported by Chinese tourists travelling abroad. It is no surprise that these same Chinese tourists tended to recommend their destinations to others as well as to revisit them after experiencing an intense "fun" emotion [63]. An extended model of goal-directed behaviour was applied by Bui and Kiatkawsin [64] for their research regarding Vietnamese hard-adventure tourists. They concluded that marketing needs to focus on information and building a favourable 
attitude, because they discovered that the direct impact on a visiting intention by robust tourists were, first and foremost, an attitude and an anticipated positive emotion. These were the two most important factors. Nonetheless, the confidence of such tourists require bolstering by information regarding tour routes, available protective equipment, relevant insurance policies and such [64]. This study by Bui and Kiatkawsin [64] concluded that a favourable attitude forms as a result of providing illustrations about how participation potentially fosters emotional responses. Low-carbon service operations constituted the focus of the research by Chang et al. [65] who looked into sustainable cultural tourism and explored the impact on it by responsible tourist behaviour. The two important elements for sustainable island tourism that outcropped by conducting primary and secondary data analysis were the supply and a demand side of a destination. Low-carbon service operations constitute the supply side, involving the regular food and lodging services but adding ecological tourist activities. Meanwhile the behaviours of those buyers of tourism reflect the demand side. Cognition, emotion and motivation along with their authenticity express such demand [65]. Happiness or sadness, e.g., reference a reaction to an incorporation of personal feelings, i.e., an emotion. Individual experiences of reality are what emotions represent [66]. For example, backpacking tourists require sustainable travel in a natural environment. Walking, riding bicycles or trains, driving, camping out-these all result in feeling "enjoyment" or "happiness"; however only for some. Others would view all those mentioned recreational activities as hardships [65]. The ethical choices consumers make often rely on emotions, as Malone et al. [67] examined. These scholars focused on ethical tourism as they examined the relationship between pleasure and ethical tourism consumption due to hedonic values. Emotions play their roles in ethical tourism, according to the experiences reported by numerous tourists, along with the sorts of hedonic values they experienced in their interactions. This bolsters the idea about the key roles played by emotions when it comes to influencing and motivating ethical choices. Furthermore this also forms the experiences buyers derived by consuming ethical tourism [67].

Scholars and practitioners [68-71] discussed the impact COVID-19 was having on tourism by directing much attention to the subject of emotions and the play of their related values. The hospitality industry, for one, has faced unprecedented challenges in the face of the current pandemic. Hospitality businesses were forced to shut down, albeit this presumably being temporary, due to most or all measures taken to flatten the curve on COVID-19 cases like community lockdowns, social distancing, stay-at-home orders and other restrictions on travel and mobility. The resulting closure of many business operations significantly decreased demand, thereby decreasing operations even more and diminishing chances for ultimate survival [68]. Time and surrounding conditions cause changes in consumer behaviours. The differences produced depend on the hedonic and utilitarian values that had effectively aroused purchasing behaviours. For example, the current COVID-19 pandemic has been responsible for a shift in consumption behaviours. People express their values and behaviours differently under conditions of insecurity when life itself is being threatened [69]. A finding by Ozturk [69] indicates that, under high-risk conditions like the COVID-19 pandemic or other such situations, people tend to purchase food for their hedonic or utilitarian value, something that positively affects online shopping. Another study by Ahn and Kwon [70] analysed economic, hedonic, social and altruistic values in their discussion regarding integrated resort destinations in Malaysia. Green practices may have attracted significant interest by the tourism and hospitality industry recently; however, studies on the factors contributing to positive behaviours by consumers have been lacking. Hence the Ahn and Kwon [70] study focuses on the attitudinal loyalty tourists may feel for a green hotel. The cognitive-affective-conative framework can explicitly serve as the basis for a model studying how cognitive evaluation involving perceived cost and value, affective responses involving positive/negative anticipated emotions and attitudes as well as a conative sense involving behavioural intentions link together. Apparently, according to the findings, consumers' perceived values have expressed both positive and negative emotions relevant to received benefits. These results reveal the importance of prior 
experiences in forming the attitudes of consumers regarding their intended behaviours pertinent to different brand names of green hotels. A research gap has been filled by this study by Ahn and Kwon [71] about how attitudinal loyalty forms among consumers and its mechanisms regarding green hotels. Meanwhile a strategy of rehousing individuals led to less homelessness in society due to social value co-creation, as per Ratten [72]. Social welfare policy makers targeted hotels and apartment units previously serving tourist needs to house homeless people in the wake of the societal effects caused by COVID-19. Previously this had not been possible, since housing accommodations had involved solely profit generating activities [72]. Other research findings involved consumer views regarding sit-down restaurants. Apparently some $25 \%$ of reviewed consumers reported they would only feel comfortable about eating out when there is a significant improvement in testing, tracing and isolating COVID-19 cases. Then, some $18 \%$ of reviewed consumers reported only feeling comfortable visiting destinations or hotels when the area had very few COVID19 cases coupled with an ability to test, trace and isolate COVID-19 cases. Additionally some $14 \%$ of potential consumers reported discomfort about going to a sit-down restaurant and some $17 \%$ about traveling and staying at a hotel before the availability of a COVID-19 vaccine appears [73]. Making matters worse, travel and tourism services require upholding social distancing regulations due to COVID-19. Services had to be provided devoid of any close interactions between customers and employees to safeguard from COVID-19 infections. Thus the most appropriate substitutes proved to be AI service devices to permit implementation of social distancing regulations and thereby decrease needed interactions with human employees [74].

The above two paragraphs pave the way for further research regarding the integration of the multi-attribute market value assessment (MAMVA) [75,76] approach and others for further development. Thereby a new technique might be developed for investigating the potential of sustainable rural tourism pertinent to quantitative and qualitative indicators for alternative selections. The potential of sustainable rural tourism could then be examined by comparing the best-performing alternative, as per such a new technique, to determine an alternative's efficiency and utility degree. Values defining the potential efficiency of sustainable rural tourism can vary from $0 \%$ to $100 \%$ when applying MAMVA. A visual assessment of the potential efficiency of sustainable rural tourism thus becomes realistic. The potential efficiency of sustainable rural tourism along with the pertinent market, hedonic and customer-perceived values become directly proportional to a system consisting of adequate indicators that includes the indicator weights and values. Consequently the results of this research in combination with neuro decision matrices $[77,78]$ and MAMVA method $[75,76]$ can serve as the basis for determining the market, hedonic and customerperceived values of the potential of sustainable rural tourism.

To apply all this, it is necessary to introduce innovation in rural tourism. Innovation helps to exploit tourism potentials in creating an attractive tourism product. Cetin et al. [79] suggested that nature should be protected in certain rural areas. This nature protection will strengthen the sustainability and design of the landscape and provide the development of tourist activities. Roman et al. [80] said that innovation in tourism should help create an original tourism product and provide a professional marketing mix for the natural and cultural assets of a particular area. The application of innovation in tourism will enable the use of tourism potentials and improve tourism in these areas [81]. However, the application of innovation in tourism requires planning activities and development of adequate policies to apply innovation in tourism in a particular area [82]. By encouraging innovation in tourism, it is possible to improve a country's competitiveness [83].

The determination of a system, its values, the decision criteria weights, validation of the developed evaluation approach and other factors are involved in a decision making process that, in and of itself, depends highly on experts. The potential of incorporating neuro decision-making and neuro-questionnaires are possible for use in future research, which could improve the decision-making process. Thus this multifaceted decision process then offers interested parties an opportunity for more effective and reliable interpretations. 


\section{Conclusions}

Tourism potential is the first step in carrying out tourism activities. It is necessary to determine the tourist potential of certain areas and build a tourist offer based on this potential. Without the tourist potential of a certain settlement, it is difficult to develop tourism in that area. The Brčko District Government is focused on development of the economy, tourism, and agriculture in different strategies. The development of tourism in Brčko District needs to be implemented in all areas. Since most of the territory of Brčko District is a rural area, it is necessary to develop tourism in these areas. This study was conducted in cooperation with the Brčko District Government. The aim was to explore the rural tourism potential of Brčko District. To achieve this goal, an expert assessment of rural tourism potential of Brčko District was used. In cooperation with the Department of Tourism of the Government of Brčko District, experts were selected, and a model was created to examine rural tourism potential. Six rural settlements were selected together with experts. The results showed that the observed rural settlements have good tourism potential. The best results were shown by the rural settlement of Bijela, while the worst results among selected in terms of tourist potential were shown by the settlement of Grbavica. To improve the tourist potential, it is necessary to improve social and economic resources in these areas. The Brčko District Government needs to improve the conditions prevailing in these rural settlements to develop tourism.

The disadvantage of this study is that not all rural areas in the territory of Brčko District were taken into analysis. However, those settlements that currently have good tourism potential were taken. When tourism in Brčko District is further developed, this will affect the tourism potential of other rural settlements to be improved. Thus, it is necessary to include these rural settlements in future research. Furthermore, the limitation of this study is that only three experts who assessed the rural tourism potential in Brcko District participated, especially because the opinion of the first expert differed from the others in terms of the importance of the criteria. The primary reason why the opinions of these experts were taken is the inability of more experts to participate due to the pandemic caused by the COVID-19 virus and the inability of more experts to participate. In future research of rural potentials of the Brčko District, it is necessary to include more experts to consider the different opinions of experts, which was partially considered in this study in terms of determining the importance of criteria and sub-criteria.

The conducted research provided a good basis for development of models for testing not only rural but also other types of tourism. The analysis of examination of results showed that the results given by the fuzzy MARCOS method do not differ from other fuzzy methods, so this method can be used in future research without restrictions. When determining the weight of criteria and sub-criteria, it is necessary to conduct research and determine which of the methods is the easiest to apply and at the same time gives reliable results to improve the implemented methodology with some other methods. In the following studies, the model needs to be improved so that it can be used in all branches of tourism. Several criteria need to be included to identify key resources for determining tourism potential. Based on that, new models could be created for determining tourist potential and other forms of tourism. The conducted research and applied methodology provide a good basis for examining tourism potential. Based on the results of this research, the necessary information is obtained on how to improve the rural tourism potentials in Brčko District.

Author Contributions: Conceptualization A.P. and F.C.; methodology A.P. and D.P.; writing-review and editing I.S., A.K. and A.P.; funding acquisition A.M. and A.P. All authors have read and agreed to the published version of the manuscript.

Funding: This paper has been partially funded by Department of Economics-University of Molise- Italy.

Institutional Review Board Statement: Not applicable.

Informed Consent Statement: Not applicable. 
Data Availability Statement: Data is contained within the article.

Acknowledgments: This work was supported by the European Commission Erasmus+ CBHE Project 610012, 'Building Resilience in Tropical Agro-Ecosystems (BRITAE). The European Commission support for the production of this publication does not constitute an endorsement of the contents which reflects the views only of the authors, and the Commission cannot be held responsible for any use which may be made of the information contained therein.

Conflicts of Interest: The authors declare no conflict of interest.

\section{References}

1. Zolfani, S.H.; Sedaghat, M.; Maknoon, R.; Zavadskas, E. Sustainable tourism: A comprehensive literature review on frameworks and applications. Econ. Res. Ekon. Istraživanja 2015, 28, 1-30. [CrossRef]

2. Ullah, Z.; Johnson, D.; Micallef, A.; Williams, A.T. Coastal scenic assessment: Unlocking the potential for coastal tourism in rural Pakistan via Mediterranean developed techniques. J. Coast. Conserv. 2009, 14, 285-293. [CrossRef]

3. Rozman, Č.; Potočnik, M.; Pažek, K.; Borec, A.; Majkovič, D.; Bohanec, M. A multi-criteria assessment of tourist farm service quality. Tour. Manag. 2009, 30, 629-637. [CrossRef]

4. Gao, J.; Wu, B. Revitalizing traditional villages through rural tourism: A case study of Yuanjia Village, Shaanxi Province, China. Tour. Manag. 2017, 63, 223-233. [CrossRef]

5. Lun, L.-M.; Pechlaner, H.; Volgger, M. Rural Tourism Development in Mountain Regions: Identifying Success Factors, Challenges and Potentials. J. Qual. Assur. Hosp. Tour. 2016, 17, 389-411. [CrossRef]

6. Adeyinka-Ojo, S.F.; Khoo-Lattimore, C. Slow food events as a high yield strategy for rural tourism destinations. Worldw. Hosp. Tour. Themes 2013, 5, 353-364. [CrossRef]

7. Yan, L.; Gao, B.W.; Zhang, M. A mathematical model for tourism potential assessment. Tour. Manag. 2017, 63, 355-365. [CrossRef]

8. Rozman, Č.; Maksimović, A.; Puška, A.; Grgić, Z.; Pažek, K.; Prevolšek, B.; Ćejvanović, F. The Use of Multi Criteria Models for Decision Support System in Fruit Production. Erwerbs-Obstbau 2017, 59, 235-243. [CrossRef]

9. Sánchez-Rivero, M.; Sánchez-Martín, J.-M.; Gallego, J.I.R. Methodological approach for assessing the potential of a rural tourism destination: An application in the province of Cáceres (Spain). Curr. Issues Tour. 2014, 19, 1084-1102. [CrossRef]

10. Boys, K.A.; White, K.D.; Groover, G. Fostering rural and agricultural tourism: Exploring the potential of geocaching. J. Sustain. Tour. 2017, 25, 1474-1493. [CrossRef]

11. Halseth, G.; Meiklejohn, C. Indicators of Small Town Tourism Development Potential: The Case of Fouriesburg, South Africa. Urban. Forum 2009, 20, 293-317. [CrossRef]

12. Jesus, C.; Franco, M. Cooperation networks in tourism: A study of hotels and rural tourism establishments in an inland region of Portugal. J. Hosp. Tour. Manag. 2016, 29, 165-175. [CrossRef]

13. Lane, B.; Kastenholz, E. Rural tourism: The evolution of practice and research approaches—towards a new generation concept? J. Sustain. Tour. 2015, 23, 1133-1156. [CrossRef]

14. Su, M.M.; Wall, G.; Wang, Y.; Jin, M. Livelihood sustainability in a rural tourism destination-Hetu Town, Anhui Province, China. Tour. Manag. 2019, 71, 272-281. [CrossRef]

15. Puška, A.; Šadić, S.; Maksimović, A.; Stojanović, I. Decision support model in the determination of rural touristic destination attractiveness in the Brčko District of Bosnia and Herzegovina. Tour. Hosp. Res. 2020, 20, 387-405. [CrossRef]

16. Muresan, I.C.; Oroian, C.F.; Harun, R.; Arion, F.H.; Porutiu, A.; Chiciudean, G.O.; Todea, A.; Lile, R. Local Residents' Attitude toward Sustainable Rural Tourism Development. Sustainability 2016, 8, 100. [CrossRef]

17. Jepson, D.; Sharpley, R. More than sense of place? Exploring the emotional dimension of rural tourism experiences. J. Sustain. Tour. 2014, 23, 1157-1178. [CrossRef]

18. Zhou, L. Online rural destination images: Tourism and rurality. J. Destin. Mark. Manag. 2014, 3, 227-240. [CrossRef]

19. Christou, P.; Farmaki, A.; Evangelou, G. Nurturing nostalgia?: A response from rural tourism stakeholders. Tour. Manag. 2018, 69, 42-51. [CrossRef]

20. Steel, G. Local encounters with globetrotters. Ann. Tour. Res. 2012, 39, 601-619. [CrossRef]

21. Trukhachev, A. Methodology for Evaluating the Rural Tourism Potentials: A Tool to Ensure Sustainable Development of Rural Settlements. Sustainability 2015, 7, 3052-3070. [CrossRef]

22. Puška, A.; Stojanović, I.; Maksimović, A. Evaluation of sustainable rural tourism potential in Brčko district of Bosnia and Herzegovina using multi-criteria analysis. Oper. Res. Eng. Sci. Theory Appl. 2019, 2, 40-54. [CrossRef]

23. Hwang, J.; Lee, S.W. The effect of the rural tourism policy on non-farm income in South Korea. Tour. Manag. 2015, 46, 501-513. [CrossRef]

24. Kim, B.-R. Agri-Tourism and its Internationalization Strategy. Int. Area Rev. 2010, 13, 3-19. [CrossRef]

25. Bassey, B.E. Transforming the Nigeria tourism industry through tourism entrepreneurial development. Afr. J. Bus. Manag. 2015, 9 , 569-580. [CrossRef]

26. Valjarević, A.; Vukoičić, D.; Valjarević, D. Evaluation of the tourist potential and natural attractivity of the Lukovska Spa. Tour. Manag. Perspect. 2017, 22, 7-16. [CrossRef]

27. Croes, R.; Rivera, M.A. Tourism's potential to benefit the poor. Tour. Econ. 2017, 23, 29-48. [CrossRef] 
28. Anbalagan, K.; Lovelock, B. The potential for coffee tourism development in Rwanda-Neither black nor white. Tour. Hosp. Res. 2014, 14, 81-96. [CrossRef]

29. Barbe, F.T.; Triay, M.G.; Häufele, C. The competitiveness of the Uruguayan rural tourism sector and its potential to attract German tourists. Compet. Rev. 2016, 26, 166-187. [CrossRef]

30. Wise, N.; Mulec, I.; Armenski, T. Towards a new local tourism economy: Understanding sense of community, social impacts and potential enterprise opportunities in Podgrađe Bač, Vojvodina, Serbia. Local Econ. J. Local Econ. Policy Unit 2017, 32, 656-677. [CrossRef]

31. Liaghat, M.; Shahabi, H.; Deilami, B.R.; Ardabili, F.S.; Seyedi, S.N.; Badri, H. A Multi-Criteria Evaluation Using the Analytic Hierarchy Process Technique to Analyze Coastal Tourism Sites. APCBEE Procedia 2013, 5, 479-485. [CrossRef]

32. Zhou, Y.; Maumbe, K.; Deng, J.; Selin, S.W. Resource-based destination competitiveness evaluation using a hybrid analytic hierarchy process (AHP): The case study of West Virginia. Tour. Manag. Perspect. 2015, 15, 72-80. [CrossRef]

33. Wang, L.-E.; Cheng, S.; Lin-Sheng, Z.; Mu, S.-L.; Dhruba, B.G.C.; Ren, G.-Z. Rural tourism development in China: Principles, models and the future. J. Mt. Sci. 2013, 10, 116-129. [CrossRef]

34. Do, Q.H.; Chen, J.-F. Prioritizing the Factor Weights Affecting Tourism Performance by FAHP. Int. J. Eng. Bus. Manag. 2013, 5, 51. [CrossRef]

35. Oh, M.; Kim, S.-S.; Lee, A. Development of an Evaluation Scale for Inter-Country Tourism Industry Competitiveness using the Delphi Technique and Analytic Hierarchy Process. Int. J. Tour. Sci. 2013, 13, 1-32. [CrossRef]

36. Lin, L.-Z.; Lu, C.-F. Fuzzy Group Decision-Making in the Measurement of Ecotourism Sustainability Potential. Group Decis. Negot. 2012, 22, 1051-1079. [CrossRef]

37. Peng, K.-H.; Tzeng, G.-H. Exploring heritage tourism performance improvement for making sustainable development strategies using the hybrid-modified MADM model. Curr. Issues Tour. 2019, 22, 921-947. [CrossRef]

38. Zhang, H.; Gu, C.-L.; Gu, L.-W.; Zhang, Y. The evaluation of tourism destination competitiveness by TOPSIS \& information entropy-A case in the Yangtze River Delta of China. Tour. Manag. 2011, 32, 443-451. [CrossRef]

39. Ilban, M.O.; Yıldırım, H.H. Determination of tourism activities of the world's best tourism destinations using the multi-criteria decision-making method. Cogent Soc. Sci. 2017, 3. [CrossRef]

40. Botti, L.; Peypoch, N. Multi-criteria ELECTRE method and destination competitiveness. Tour. Manag. Perspect. 2013, 6, 108-113. [CrossRef]

41. Huang, J.-H.; Peng, K.-H. Fuzzy Rasch model in TOPSIS: A new approach for generating fuzzy numbers to assess the competitiveness of the tourism industries in Asian countries. Tour. Manag. 2012, 33, 456-465. [CrossRef]

42. Lopes, A.P.F.; Muñoz, M.M.; Alarcón-Urbistondo, P. Regional tourism competitiveness using the PROMETHEE approach. Ann. Tour. Res. 2018, 73, 1-13. [CrossRef]

43. Zhu, Y.; Zhu, Q.; Zhu, Z. Modeling, Evaluation and Analysis of Tourism Destination Competitiveness: A Case Study of the Yangtze River Delta of China. Asia Pac. J. Tour. Res. 2013, 19, 932-949. [CrossRef]

44. Carayannis, E.G.; Ferreira, F.A.F.; Bento, P.; Ferreira, F.A.; Jalali, M.S.; Fernandes, B.M. Developing a socio-technical evaluation index for tourist destination competitiveness using cognitive mapping and MCDA. Technol. Forecast. Soc. Chang. 2018, 131, 147-158. [CrossRef]

45. Đurić, A.; Ćejvanović, F. Mogućnosti razvitka agroturizma u regiji Brčko distrikta Bosne i Hercegovine. In Proceedings of the 43rd Croatian and 3rd International Symposium on Agriculture, Opatija, Croatia, 18-21 February 2008; pp. $229-233$.

46. Vuković, P.; Cecić, N.; Cvijanović, D. Ruralni turizam kao okosnica turističkog razvoja Brčko distirkta. Ekon. Poljopr. 2008, 55, 83-91.

47. De Jong, A.; Varley, P. Food tourism and events as tools for social sustainability? J. Place Manag. Dev. 2018, 11, 277-295. [CrossRef]

48. Ezung, T.Z. Rural Tourism in Nagaland, India: Exploring the Potential. Int. J. Rural. Manag. 2011, 7, 133-147. [CrossRef]

49. Mikulić, J.; Krešić, D.; Prebežac, D.; Miličević, K.; Šerić, M. Identifying drivers of destination attractiveness in a competitive environment: A comparison of approaches. J. Destin. Mark. Manag. 2016, 5, 154-163. [CrossRef]

50. Pamučar, D.; Stević, Ž.; Sremac, S. A New Model for Determining Weight Coefficients of Criteria in MCDM Models: Full Consistency Method (FUCOM). Symmetry 2018, 10, 393. [CrossRef]

51. Nunić, Z. Evaluation and selection of the PVC carpentry manufacturer using the FUCOM-MABAC model. Oper. Res. Eng. Sci. Theory Appl. 2019, 1, 13-28. [CrossRef]

52. Pamučar, D.; Lukovac, V.; Bozanić, D.; Komazec, N. Multi-criteria FUCOM-MAIRCA model for the evaluation of level crossings: Case study in the Republic of Serbia. Oper. Res. Eng. Sci. Theory Appl. 2019, 1, 108-129. [CrossRef]

53. Durmić, E.; Stević, Ž.; Chatterjee, P.; Vasiljević, M.; Tomašević, M. Sustainable supplier selection using combined FUCOM Rough SAW model. Rep. Mech. Eng. 2020, 1, 34-43. [CrossRef]

54. Fazlollahtabar, H.; Smailbašić, A.; Stević, Ž. FUCOM method in group decision-making: Selection of forklift in a warehouse. Decis. Making: Appl. Manag. Eng. 2019, 2, 49-65. [CrossRef]

55. Bozanić, D.; Tešić, D.; Kočić, J. Multi-criteria FUCOM-Fuzzy MABAC model for the selection of location for construction of single-span bailey bridge. Decis. Making: Appl. Manag. Eng. 2019, 2, 132-146. [CrossRef]

56. Stević, Ž.; Pamučar, D.; Puška, A.; Chatterjee, P. Sustainable supplier selection in healthcare industries using a new MCDM method: Measurement of alternatives and ranking according to COmpromise solution (MARCOS). Comput. Ind. Eng. 2020, 140, 106231. [CrossRef] 
57. Puška, A.; Stojanović, I.; Maksimović, A.; Osmanović, N. Project Management Software Evaluation by Using the Measurement of Alternatives and Ranking According to Compromise Solution (MARCOS) Method. Oper. Res. Eng. Sci. Theory Appl. 2020, 3, 89-101. [CrossRef]

58. Stanković, M.; Stević, Ž.; Das, D.K.; Subotić, M.; Pamučar, D. A New Fuzzy MARCOS Method for Road Traffic Risk Analysis. Mathmatics 2020, 8, 457. [CrossRef]

59. Pamucar, D. Normalized weighted Geometric Dombi Bonferoni Mean Operator with interval grey numbers: Application in multicriteria decision making. Rep. Mech. Eng. 2020, 44-52. [CrossRef]

60. Adis, P.; Safet, K.; Željko, S.; Jasmin, S. A New Way of Applying Interval Fuzzy Logic in Group Decision Making For Supplier Selection. Econ. Comput. Econ. Cybern. Stud. Res. 2018, 52, 217-234. [CrossRef]

61. del Río-Rama, M.d.l.C.; Maldonado-Erazo, C.P.; Álvarez-García, J.; Durán-Sánchez, A. Cultural and Natural Resources in Tourism Island: Bibliometric Mapping. Sustainability 2020, 12, 724. [CrossRef]

62. Holbrook, M.B. Consumption experience, customer value, and subjective personal introspection: An illustrative photographic essay. J. Bus. Res. 2006, 59, 714-725. [CrossRef]

63. Chen, X.; Cheng, Z.-F.; Kim, G.-B. Make It Memorable: Tourism Experience, Fun, Recommendation and Revisit Intentions of Chinese Outbound Tourists. Sustainability 2020, 12, 1904. [CrossRef]

64. Bui, N.A.; Kiatkawsin, K. Examining Vietnamese Hard-Adventure Tourists' Visit Intention Using an Extended Model of GoalDirected Behavior. Sustainability 2020, 12, 1747. [CrossRef]

65. Chang, S.-H.; Hernández-Díaz, R.J.; Lo, W.-S. The Impact of Low-Carbon Service Operations on Responsible Tourist Behavior: The Psychological Processes of Sustainable Cultural Tourism. Sustainability 2020, 12, 4943. [CrossRef]

66. Buckley, R.C. Sustainable tourism: Research and reality. Ann. Tour. Res. 2012, 39, 528-546. [CrossRef]

67. Malone, S.; McCabe, S.; Smith, A.P. The role of hedonism in ethical tourism. Ann. Tour. Res. 2014, 44, 241-254. [CrossRef]

68. Bartik, A.W.; Bertrand, M.; Cullen, Z.B.; Glaeser, E.L.; Luca, M.; Stanton, C.T. How are Small Businesses Adjusting to Covid-19? Early Evidence from a Survey (No. w26989); National Bureau of Economic Research: Cambridge, MA, USA, 2020. [CrossRef]

69. Öztürk, R. Health or Death? The Online Purchase Intentions of Consumers during the COVID-19 Pandemic. Transnatl. Mark. J. 2020, 8, 219-241. [CrossRef]

70. Ahn, J.; Thomas, T.K. The role of customers' perceived values of integrated resort brands in destination. J. Destin. Mark. Manag. 2020, 15, 100403. [CrossRef]

71. Ahn, J.; Kwon, J. Green hotel brands in Malaysia: Perceived value, cost, anticipated emotion, and revisit intention. Curr. Issues Tour. 2019, 23, 1559-1574. [CrossRef]

72. Ratten, V. Coronavirus (covid-19) and social value co-creation. Int. J. Sociol. Soc. Policy 2020. [CrossRef]

73. Gursoy, D.; Chi, C.G.; Chi, O.H. COVID-19 Study 2 Report: Restaurant and Hotel Industry: Restau-Rant and Hotel Customers' Sentiment Analysis. Would They Come Back? If They Would, WHEN; (Report No. 2). 2020. Available online: http://www. htmacademy.com/wp-content/uploads/2020/10/Covid-19-October-study-summary-report.pdf (accessed on 10 December 2020).

74. Gursoy, D.; Chi, C.G. Effects of COVID-19 pandemic on hospitality industry: Review of the current situations and a research agenda. J. Hosp. Mark. Manag. 2020, 29, 527-529. [CrossRef]

75. Zavadskas, E.; Bausys, R.; Kaklauskas, A.; Ubarte, I.; Kuzminske, A.; Gudiene, N. Sustainable market valuation of buildings by the single-valued neutrosophic MAMVA method. Appl. Soft Comput. 2017, 57, 74-87. [CrossRef]

76. Zavadskas, E.; Bausys, R.; Kaklauskas, A.; Raslanas, S. Hedonic shopping rent valuation by one-to-one neuromarketing and neutrosophic PROMETHEE method. Appl. Soft Comput. 2019, 85, 105832. [CrossRef]

77. Kaklauskas, A.; Zavadskas, E.; Bardauskiene, D.; Cerkauskas, J.; Ubarte, I.; Seniut, M.; Dzemyda, G.; Kaklauskaite, M.; Vinogradova, I.; Velykorusova, A. An Affect-Based Built Environment Video Analytics. Autom. Constr. 2019, $106,102888$. [CrossRef]

78. Kaklauskas, A.; Jokubauskas, D.; Cerkauskas, J.; Dzemyda, G.; Ubarte, I.; Skirmantas, D.; Podviezko, A.; Simkute, I. Affective analytics of demonstration sites. Eng. Appl. Artif. Intell. 2019, 81, 346-372. [CrossRef]

79. Cetin, M.; Zeren, I.; Sevik, H.; Cakir, C.; Akpinar, H. A study on the determination of the natural park's sustainable tourism potential. Environ. Monit. Assess. 2018, 190, 167. [CrossRef]

80. Roman, M.; Roman, M.; Prus, P.; Szczepanek, M. Tourism Competitiveness of Rural Areas: Evidence from a Region in Poland. Agriculture 2020, 10, 569. [CrossRef]

81. Roman, M.; Roman, M.; Prus, P. Innovations in Agritourism: Evidence from a Region in Poland. Sustainability 2020, $12,4858$. [CrossRef]

82. Zach, F.J.; Hill, T. Network, knowledge and relationship impacts on innovation in tourism destinations. Tour. Manag. 2017, 62, 196-207. [CrossRef]

83. Hall, C.M. Innovation and tourism policy in Australia and New Zealand: Never the twain shall meet? J. Policy Res. Tour. Leis. Events 2009, 1, 2-18. [CrossRef] 